\title{
The Mediterranean Ridge: A mass balance across the fastest growing accretionary complex on Earth
}

\author{
Achim Kopf \\ Scripps Institution of Oceanography, University of California, San Diego, California, USA \\ Jean Mascle \\ Géosciences Azur, Villefranche-sur-Mer, France
}

Dirk Klaeschen

GEOMAR, Marine Geodynamics, Kiel, Germany

Received 14 February 2001; revised 11 September 2002; accepted 13 March 2003; published 7 August 2003.

[1] Depth migration of seismic reflection profiles across the Mediterranean Ridge accretionary complex between the African and Eurasian blocks illustrates profound variations in the geometry and internal structure along strike. Structural interpretations of four cross sections, together with bathymetric and acoustic surface information and drilling data, are used to volumetrically balance the amount of subduction versus accretion with time. Results suggest the existence of three distinct scenarios, with a jump in décollement in the west, intense backthrusting in the central part between Libya and Crete, and transcurrent tectonism in the east. The onset of accretion coincides with exhumation of thrust sheets $(\sim 19 \mathrm{Ma})$, followed by rapid sediment accretion with thick, evaporitebearing incoming successions facilitating outward growth of the wedge. The minimum rate of accretion (20-25\% of the total sediment supply) is observed in the central portion where the ridge suffers maximum deformation. Here the indenting leading edge of the African Plate apparently forces the sediment into subduction, or local underplating. In contrast, an estimated $40-60 \%$ of the available sedimentary input was accreted in the western domain where collision is less accentuated. The results support the hypothesis that highly destructive forearc collisional events, like slab break off and exhumation of thrust sheets, can be followed by periods of accretion and continuous growth of accretionary wedges. INDEX TERMS: 8105 Tectonophysics: Continental margins and sedimentary basins; 8010 Structural Geology: Fractures and faults; 8020 Structural Geology: Mechanics; 8150 Tectonophysics: Plate boundary_general (3040); 8168 Tectonophysics: Stresses—general; KEYWORDS: Mediterranean Ridge, accretionary prism, mass transfer, subduction zone, Messinian evaporites, forearc dynamics

Citation: Kopf, A., J. Mascle, and D. Klaeschen, The Mediterranean Ridge: A mass balance across the fastest growing accretionary complex on Earth, J. Geophys. Res., 108(B8), 2372, doi:10.1029/2001JB000473, 2003.

\section{Introduction}

[2] Parts of the eastern Mediterranean Sea represent remnants of Tethyan oceanic seafloor which have been preserved despite collision of the Arabian Plate with Eurasia, or more generally spoken, Alpine orogenesis [e.g., Hsü and Bernoulli, 1978]. This seafloor is presently subducting along the Hellenic subduction south of mainland Greece and the island of Crete, while the volcanic arc is represented by small islands (e.g., Santorini) in the southern Aegean Sea [e.g., Finetti et al., 1991]. The Mediterranean Ridge (MedRidge) accretionary complex is a more than $300 \mathrm{~km}$ wide and $\sim 2000 \mathrm{~km}$ long accretionary prism south of Greece (Figure 1a). It has been demonstrated to be the fastest outward growing wedge in most recent Earth history,

Copyright 2003 by the American Geophysical Union. 0148-0227/03/2001JB000473\$09.00 with a rate of up to $10 \mathrm{~km} \mathrm{Myr}^{-1}$ [Kastens, 1991]. Owing to numerous geophysical surveys during the previous decade [see Chaumillon et al., 1996; Harjes et al., 1997; Mascle et al., 1999; Reston et al., 2002; J. Makris, unpublished data, 2001], the geometry of the area down to depths of several $10 \mathrm{~s}$ of $\mathrm{km}$ is well imaged. The seismic reflection data illustrate profound variations in the geometry of the prism down to approximately $10 \mathrm{~km}$ [Chaumillon and Mascle, 1997]. In the west, the MedRidge reaches its maximum width $(>300 \mathrm{~km})$ by accumulating sediment from the Sirte abyssal plain (Figure 2). In the central part between Libya and Crete (Figures 3 and 4), the wedge suffers maximum deformation with reverse and backthrust faulting. Farther east toward the Herodotus abyssal plain, the MedRidge widens again (Figure 5), and backthrusting over its backstop is less pronounced. The entire prism is characterized by abundant dome- and pie-shaped mud volcanoes (see Figure 1b) [Kopf et al., 2001]. 


\section{A}

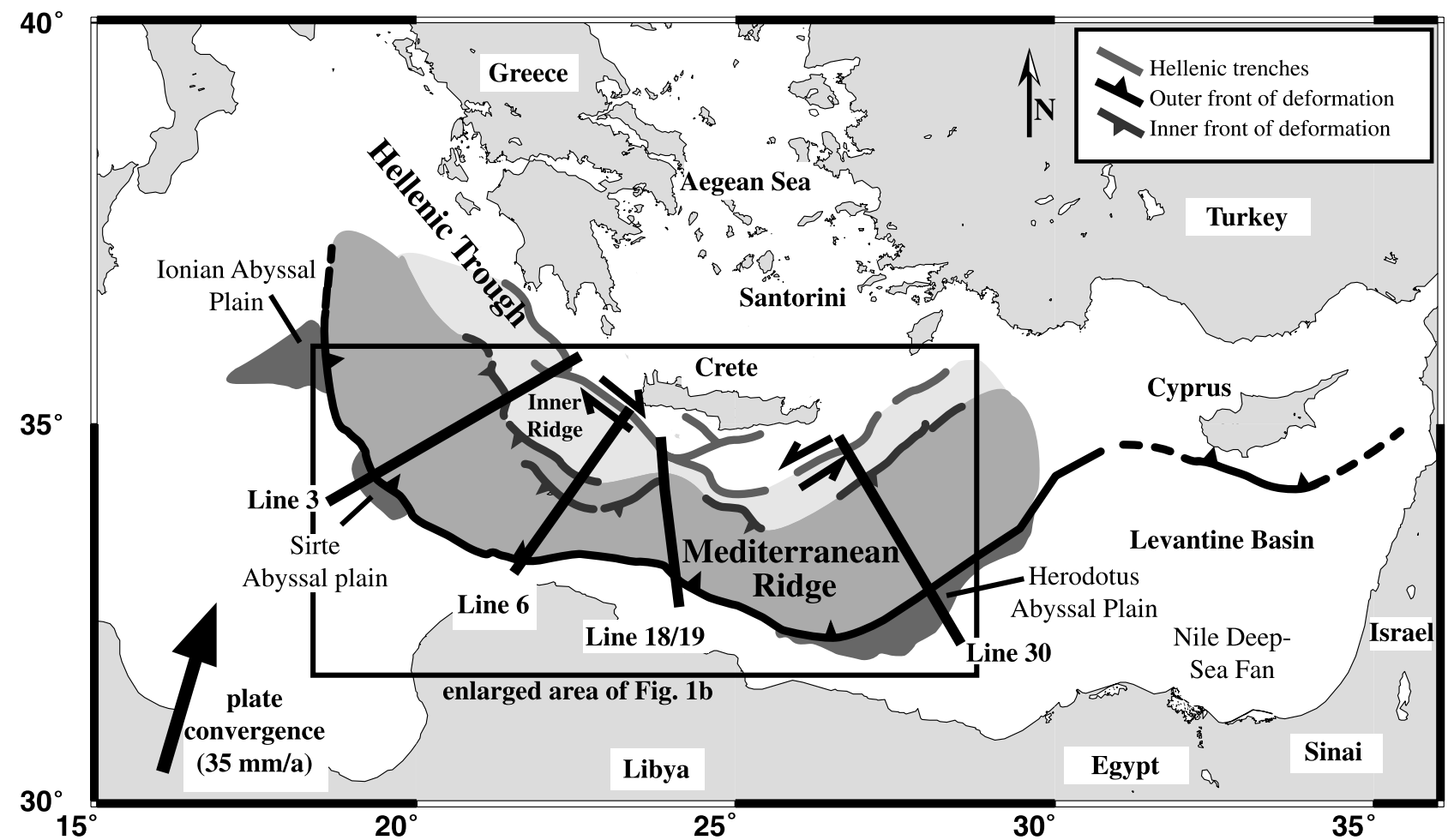

Figure 1a. Map of the eastern Mediterranean, showing the main structural elements and the four seismic profiles along which the balance study was carried out. The Aegean Sea represents the back-arc basin behind the volcanic arc, represented by islands like Santorini. Crete is a forearc topographic high, which earlier acted as the backstop to allow accretion of the Mediterranean Ridge (light shading). The areas of dark shading are the various abyssal plains on the eastern Mediterranean seafloor. The arrow indicates the present plate kinematic direction and rate between Africa and Eurasia. (Modified after Huguen [1998].)

[3] In this paper, we present a first mass balance of subducted versus accreted sediments along four cross sections of the prism (Figures 1a and 1b). Models for the sedimentary input into the Ionian and Herodotus Basins are compared to the wedge geometry along strike. The aspects addressed in this study include (a) the possible influence of rapidly deposited, overpressured sediment (Ionian Basin, Nile deep-sea fan) on the style of deformation, (b) the role of salt (Messinian evaporites) on the décollement level and rate of outward growth of the wedge, (c) the effect of accentuated deformation as a result of the impact of the Libyan margin south of Crete on rate of accretion, and (d) the long-term growth of accretionary wedges after strong changes in the regional tectonic framework (after HP/LT metamorphism and exhumation of parts of the Greek forearc). In its approach, the balance closely resembles the work of von Huene and Scholl [1991] and, to a lesser extent, Rea and Ruff [1996] but on a higher resolution in a regional context (see similar work across the South Chile forearc by Behrmann and Kopf [2001]).

\section{Geological Setting}

[4] Closure of the southern branch of the Neotethys from Late Jurassic onward affected the Hellenides, mainland Greece, most profoundly in Eocene time [Altherr et al.,
1982]. Kinematic reorganization of the Hellenic subduction zone occurred thereafter, with its most accentuated tectonic movements after closure of the relatively narrow Pindos Ocean during the upper Eocene (35 Ma; [see Robertson and Kopf, 1998]). In this section, the kinematic reconstruction is divided in two parts: The first part is concerned with the accretionary wedge and its morphostructure along strike. The second part focuses on the northern forearc (i.e., backstop), the formation of which allowed sediment accretion.

\subsection{Accretionary Complex}

[5] Independent of its degree of metamorphism, the backstop of the Hellenic subduction system represents the southernmost edge of the thinned Eurasian continental crust on top of the retreating subduction zone. It is also the boundary between compressional deformation and conjugate faulting in the distal Mediterranean Ridge and predominantly extensional deformation in the more internal part of the forearc [Le Pichon et al., 1982]. What is usually referred to as the Hellenic Trench, or Hellenic Trough (Figure 1a), represented the deformation front of the initial MedRidge during the early Miocene. However, with ongoing accretion in the Plio-Quaternary this deformation front migrated southward, so that the present-day Hellenic Trench is not a deep-sea trench in the strictest sense, but a forearc depression with very little sedimentary infill (see below). 

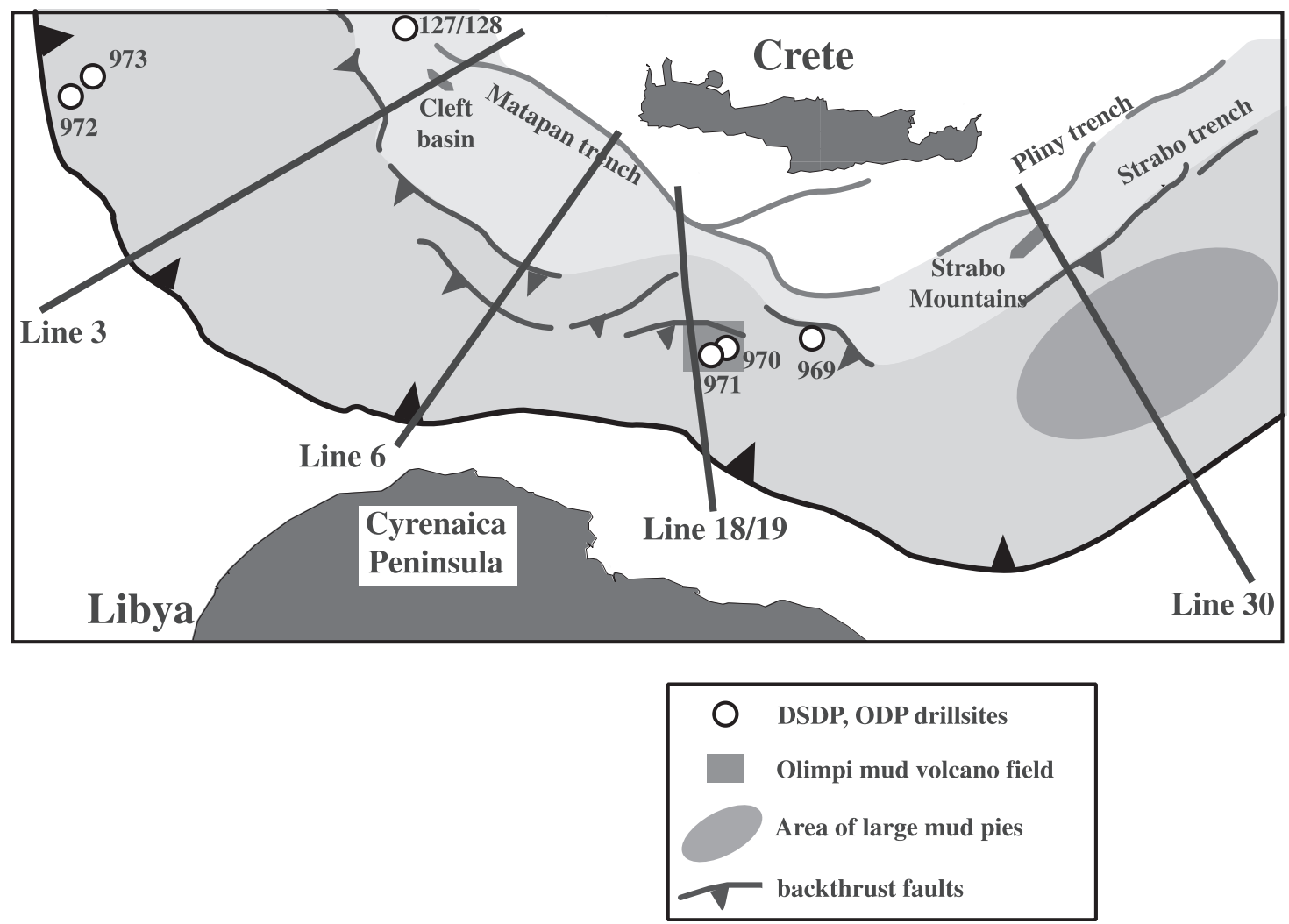

Figure 1b. Enlargement of central part of the map in Figure 1a. The different branches of the Hellenic Trough, the Matapan, Pliny, and Strabo trenches, represent forearc depressions north of the MedRidge. Numbers refer to DSDP and ODP drill sites. See legend for explanation.

Owing to the geometry of the converging African Plate, and namely the Cyrenaica Peninsula indenting into the Mediterranean Ridge (Figure 1), the accretionary prism south of the backstop suffers variable degrees of deformation.

[6] In the main collision zone between Lybia and Crete, the entire abyssal plain has undergone subduction. The entire prism is thrust onto the Libyan Margin to the south, and backthrust over the Cretan Margin to the north [Mascle et al., 1999]. The incipient compression is accommodated not only by such thrusting at the base of the prism at both front and apex, but by internal conjugate faulting. Backthrusting has caused the formation of a topographic escarpment separating the wedge from the Inner Ridge backstop (Figure 1a). The accentuation of collision in this area has been proposed to cause retardation of convergence in the central part of the Hellenic subduction zone, having started some 3-5 Myr ago [Le Pichon et al., 1995]. Evidence for uplifting of the MedRidge north of Libya is also provided by the absence of a large cover of evaporites from the latest Miocene 5-6 Ma [see Montadert et al., 1978]. The incipient collision is also thought to be responsible for the switch from active N-S extension on Crete to E-W extension in the Pliocene [Armijo et al., 1992].

[7] Farther to the west toward the Sirte abyssal plain in the Ionian Basin and the Peloponnesus (mainland Greece), deformation is less pronounced than south of Crete. The accretionary prism is wider, and numerous hypotheses have been put forward to explain the geometry of the wedge in this area, most of which favored its northern part to be metamorphic thrust sheets related to the Cyclades [e.g., Truffert et al., 1993; Lallemant et al., 1994]. Relatively high velocities from seismic wide-angle experiments (see results from IMERSE experiment in works by, e.g., IMERSE Working Group [1997] and Reston et al. [2002]) as well as gravity modeling [Truffert et al., 1993] were used to support the hypothesis. In contrast, drilling results from Sites 127/128 [Ryan et al., 1973] suggest that the backstop may be located north of the Hellenic Trench [Kastens, 1991, Figure 1]. The southern part of the MedRidge, where frontal accretion and outward growth causes landward vergent faulting, seems to be dominated by both Messinian evaporites [Reston et al., 2002] and overpressured formations on the Sirte abyssal plain (see detailed description in section 4.1).

[8] Southeast of Crete, the Herodotus abyssal plain (Figure 1a) with several kilometer thick hemipelagic sediments is consumed beneath a much wider prism than between Libya and Crete. The wedge shows gentle folding and faulting, while the backstop to the prism, represented by the rudimentary Inner Ridge and the elevated Strabo Mountains (Figure $1 \mathrm{~b}$ ), is overridden by the accreted material. Up to more than $30 \mathrm{~km}$ wide mud pies overlie the faulted central wedge [Kopf et al., 2001]. The main driving force for extrusion of overpressured muds are transtensional forces due to oblique subduction (J. Makris, personal communication, 2000).

\subsection{Forearc and Backstop Region}

[9] When regarding an accretionary system, the backstop domain is of particular interest, as it is one of the major 
EPM $1-4$ KOPF ET AL:: MASS BALANCE ACROSS THE MEDITERRANEAN RIDGE
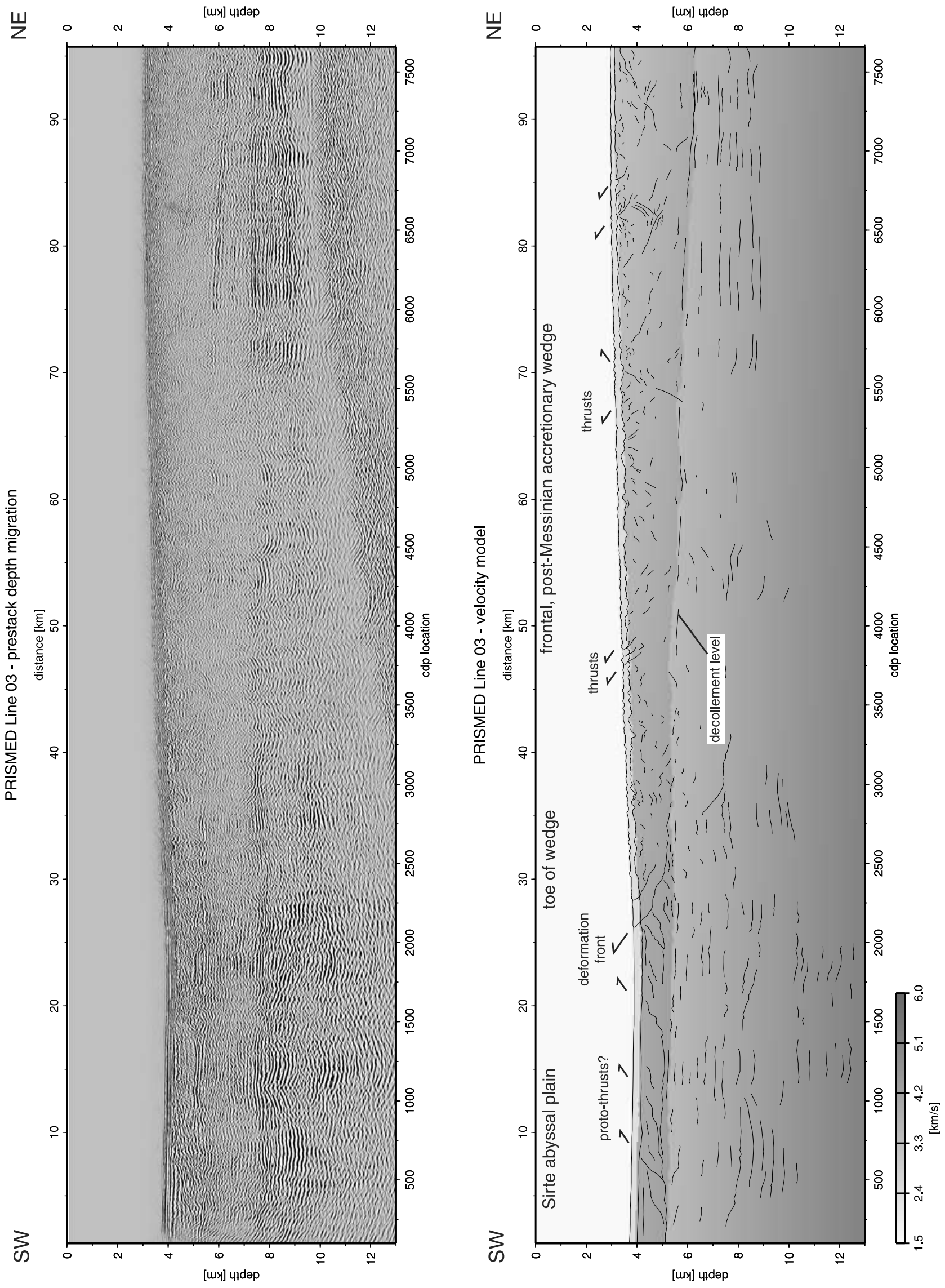
controls of the amount of sediment transfer from the lower to the upper plate. This equally applies to the "subduction gate" at depth and to the geometry of the continental abutment of the leading edge of the forearc [e.g., Kukowski et al., 1994].

[10] Seismic tomography studies in the eastern Mediterranean region have aimed to image the position of the slab at greater depths, revealing a northward dipping zone with velocities exceeding PREM values by between about +1 and $+2 \%$ to a depth of approximately $600 \mathrm{~km}$ [Spakman, 1986; Meulenkamp et al., 1988; Wortel et al., 1990; Ligdas et al., 1992]. In the upper $400 \mathrm{~km}$, this feature is congruent to the Benioff zone and consequently interpreted to represent the downgoing African plate at a depth of 50-60 km. Its total length can be divided into about $200-250 \mathrm{~km}$ beneath the present-day accretionary prism, and another $150-250 \mathrm{~km}$ beneath the backstop domain of the Hellenic forearc (including Crete as its prominent outer arc high).

[11] The nature of the material forming the forearc wedge is still poorly constrained. Between the magmatic arc and the accretionary complex, the forearc is underlain by Aegean continental crust thinning southward to less than $16 \mathrm{~km}$ beneath the Sea of Crete [Makris and Stobbe, 1984]. Although a local increase in crustal thickness is inferred beneath Crete, the leading edge of the Aegean crust south of the island again ranges between 15 and $20 \mathrm{~km}$ thickness [Makris and Stobbe, 1984; Truffert et al., 1993; Lallemant et al., 1994]. In the shallow part of the forearc, asymmetric graben structures reflect the response of the brittle upper crust to extension. This area comprises a stack of tectonic thrust nappes [e.g., Fassoulas et al., 1994], the deepest of which result from deep subduction and exhumation during the early Miocene [e.g., Jolivet et al., 1996; Thomson et al., 1998, 1999]. Recent thermochronologic studies imply that subduction of the high-pressure/low-temperature (HP/LT) units began between 36 and $29 \mathrm{Ma}$, and peak conditions of metamorphism of $10 \pm 2 \mathrm{kbar}$ and $400 \pm 50^{\circ} \mathrm{C}$ were reached between 24 and $19 \mathrm{Ma}$ in western Crete [Thomson et al., 1998, 1999]. Rapid exhumation to $<10 \mathrm{~km}$ depth and $<300^{\circ} \mathrm{C}$ at rates $>4 \mathrm{~km} \mathrm{Myr}^{-1}$ was completed before $19 \mathrm{Ma}$ [Thomson et al., 1998], and has been related to a model of tectonic unroofing driven by subduction roll back associated with slab-pull, collision, and slab break off, as proposed for the Aegean [Davies and von Blanckenburg, 1995]. As a result of the break off, the HP/LT rock of a subducted microcontinent rose due to its low density ("buoyant escape") into the space created by the initiation of renewed subduction and rollback of the southern branch of the Neotethys. The exhumed block consists of the Phyllite-Quartzite Unit, a series of metamorphosed siliciclastic rocks, and the Plattenkalk unit, formerly platform carbonates of a foreland environment [e.g., Theye and Seidel, 1993]. These HP/LT units and their overburden of units of the "upper nappes" and Neogene basin sediments [Bonneau, 1984; Fassoulas et al., 1994] then acted as the abutment to allow accretion of sediments riding on Neotethyan seafloor (for details, see Robertson and Kopf [1998, Figures 6 and 7]).
[12] Farther west on the Peloponnesus, mainland Greece (see Figure 1a), units similar to those of the exhumed microcontinent can be found. In fact, the entire external Hellenides are characterized by a more or less continuous late Oligocene/early Miocene HP belt [e.g., Seidel et al., 1982]. As for the equivalent to the Phyllite-Quartzite Unit, the "Pharnon Phyllites" [Bassias and Triboulet, 1985] have experienced even higher pressures $(17 \pm 4 \mathrm{kbar})$ at temperatures around $450^{\circ} \mathrm{C}$ [Theye and Seidel, 1993]. Similarly, the former foreland carbonates of the Peloponnesus have suffered deeper subduction than their Cretan counterparts before being exhumed in the earliest Miocene [Theye and Seidel, 1993]. Consequently, we assume that exhumation of the HP/LT units occurred more or less simultaneously in the study area, which were operative as a backstop to sediment accretion since at least $19 \mathrm{Ma}$. However, we cannot rule out that the preexisting Cretaceous body of rock may have accumulated an accretionary wedge which was not eroded by the subduction-exhumation cycle. Such a scenario does not appear likely, and no evidence for pre-Miocene accreted strata has been found in the MedRidge.

\section{Database and Methods}

[13] After having set the stage as far as the regional geology is concerned, we discuss the geophysical database as well as the various controlling parameters for the mass balance study. There may be some errors involved in each of the actual numbers, be they velocities for migration of seismic data, plate kinematic and sedimentation rates, or onset of accretion in the first place. We do not quantify these errors, and hence have no error bars at the resulting numbers in the balance data. We do, however, give a detailed report about the compilation and processing of data on a step-by-step basis, so that the reader can follow us through and can decide where we may err. The end products, like rate of subducted solid mass, percentage of accreted mass, or rate of outward growth of the wedge, are numbers which bear some uncertainties. This is natural for a study like this, and we do not claim our numbers to be the correct ones, but, to our best knowledge, the most likely ones.

\subsection{Geophysical Data: MCS Data Acquisition and Processing}

[14] Two different sets of MCS (multichannel seismic) data collected in the study area provide complementary data (Figure 1). During the PrisMed 1 (PM1) survey in 1993, 96-channel seismic data were acquired [Avedik et al., 1993|. Parts of the demultiplexed data underwent preprocessing on board using the commercial SPW (Parallel Geosciences) processing package [Chaumillon, 1995]. Onshore preprocessing included trace editing, CDP sorting, spherical divergence correction, deconvolution, fk filtering, and frequency domain filtering, all carried out with GLOBE Claritas processing software.

Figure 2. (opposite) (top) SSW-NNE oriented, prestack depth-migrated PRISMED seismic line 3 across the accretionary wedge, showing how shortening is accommodated by conjugate faulting (central domain) and backthrusting (inner domain, apex). Note also some landward vergent protothrusts (SW end of line), the downstepping décollement farther north, and the Cleft basin in the backstop domain (NE end of line). (bottom) Structural line drawing overlying the 2-D velocity model. 
EPM $1-6$ KOPF ET AL.: MASS BALANCE ACROSS THE MEDITERRANEAN RIDGE
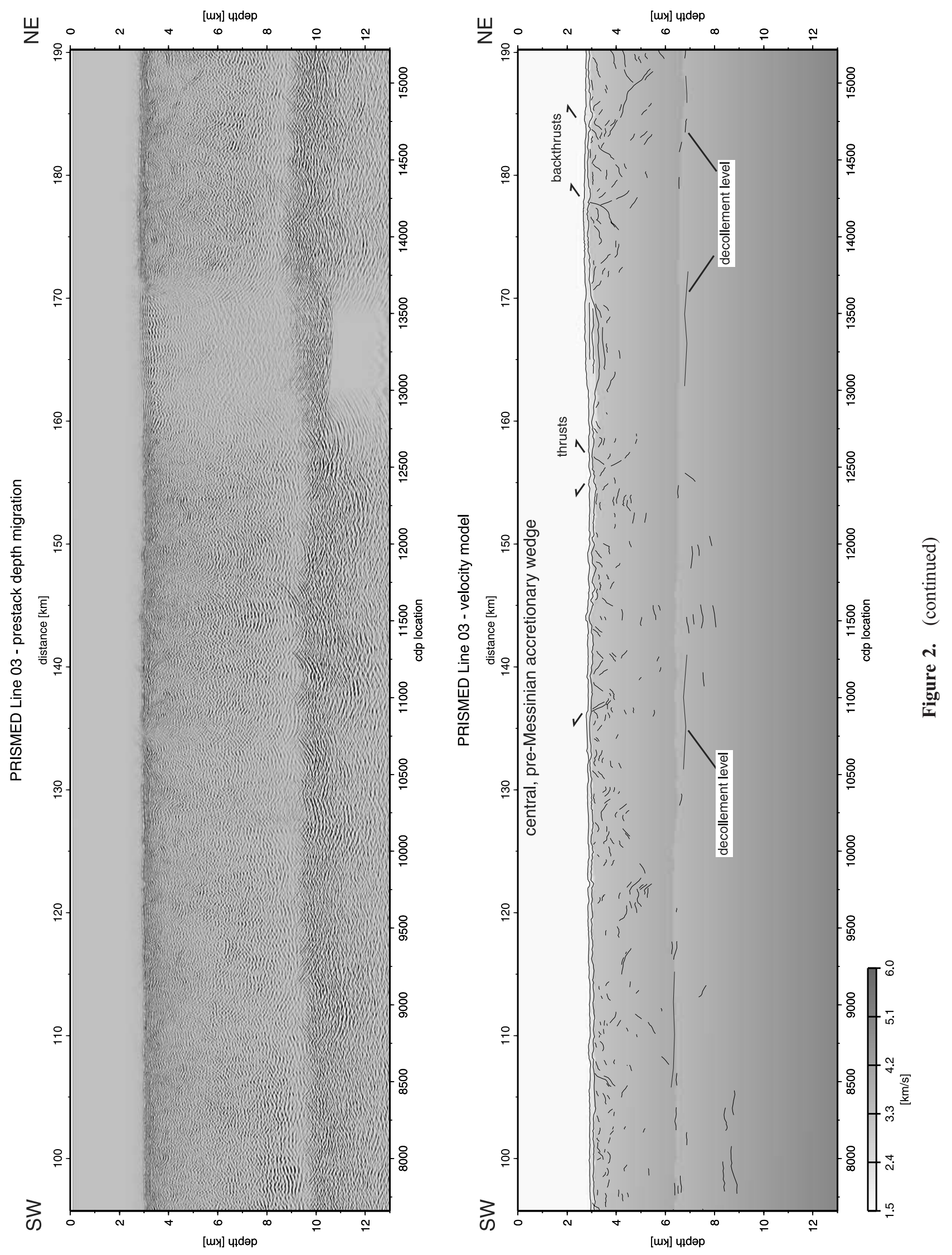

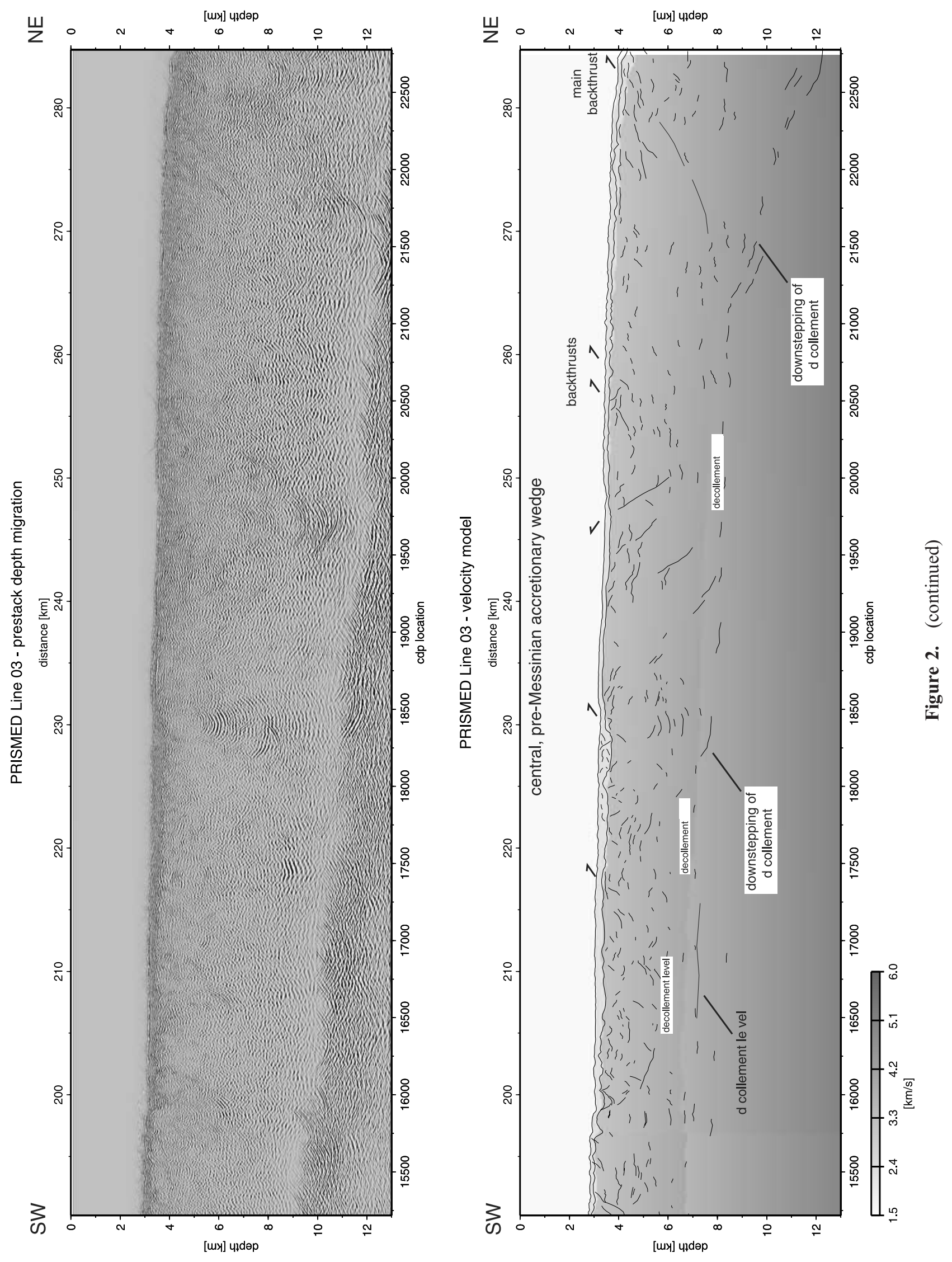

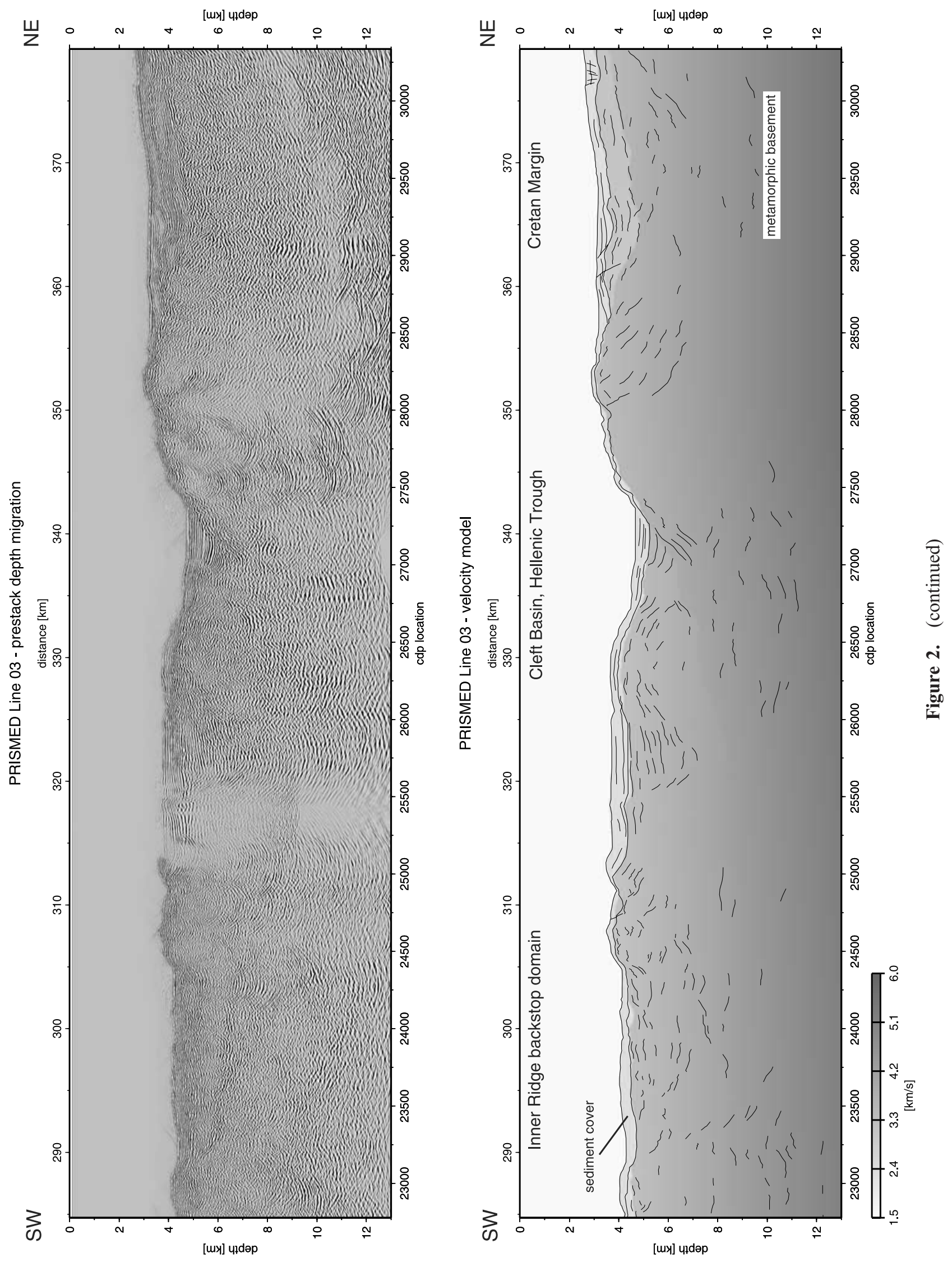
[15] Given that the seismic images of accretionary systems consist of predominantly dipping reflectors and pronounced lateral velocity gradients, conventional CMP velocity analyses of MCS data often fail to provide good regional estimates of seismic velocity and subsurface image. To overcome such problems, we used a combination of iterative prestack depth migration and focusing analyses to determine a geologically plausible velocity model resulting in a true depth subsurface image for detailed structural interpretation. Depth migration does not only produce a section in depth, but (in contrast to conventional processing and imaging) also corrects refraction and bending of the rays at velocity interfaces and gradients [Hubral, 1977] according to Snell's law. Such effects may become particularly important when features like high-velocity salt structures juxtapose against low-velocity sediments, as is the case in the uppermost Miocene deposits in parts of the eastern Mediterranean. The prestack depth migration algorithm, which was used to image and analyze reflective boundaries, is part of the commercial Kirchhoff migration package KirPack (SIRIUS, GX Technology), and includes focusing depth error analysis each 80 CMP locations apart for quality control [MacKay and Abma, 1992]. Each seismic profile underwent a number of migrations using a velocity model on a "one layer at the time" basis. First, the water velocity is estimated for the area, and an iteration is run. Then, the second iteration is run with a presumed velocity for the uppermost sedimentary layers, and so on. This procedure was repeated five to ten times (depending on the complexity of the seismic profile in question; see Figures 2-5). The upper limit for the velocity values was chosen to be $6 \mathrm{~km} \mathrm{~s}^{-1}$, as has been suggested from wideangle data in the eastern Mediterranean [Makris et al., 1994]. In areas of complex and largely unknown lithology (like the backstop domains), detailed models across characteristic boundaries used "velocity scans" to allow comparison of the same data example migrated with different velocities $300 \mathrm{~m} \mathrm{~s}^{-1}$ apart. Comparison then allows selection of the velocity model in favor from depth focusing analyses and based on quality of the seismic image. As one crucial result for this study, the backstop to the accretionary prism south of Crete can be demonstrated to have elevated velocities in the units beneath the prominent northeast dipping reflections (see Figure 6, and constraints for the models below).

\subsection{Previous Evidence for the Initiation of Accretion}

[16] A wide range of studies focused on the initiation of accretion in the Hellenic subduction zone, having resulted in an equally wide range of results.

[17] Tomographic images of the Aegean/eastern Mediterranean crust and mantle have been published by Spakman [1986] and Spakman et al. [1988], but the significance of these models has been debated [Ligdas et al., 1992]. The general finding is a difference in length of the African slab beneath the MedRidge and Crete on one hand (near our line 18/19), and beneath the MedRidge farther west on the other hand (near our line 3, Figure 1). While in the first image (profile AA' of Spakman et al. [1988]), the top of the slab can be traced approximately $600 \mathrm{~km}$ behind the deformation front, it is imaged almost $800 \mathrm{~km}$ long at the western branch (profile BB' of Spakman et al. [1988]). However, the meaning of these images is questionable given that this implies continuous subduction over almost $50 \mathrm{Myr}$ in case of the latter example. Given the gaps in the slab image of +1 to $+3 \%$ PREM magnitude, we conclude that constant growth of the wedge since the middle Eocene is unlikely.

[18] The second line of evidence for initiation of accretion has been derived from studies on rocks sampled onshore and offshore. The marine drill sites, which represent crucial constraints for the subduction/accretion history, are shown in Figure 1b. DSDP Sites 127/128 were drilled immediately north of the Hellenic Trench (Matapan branch, Figure $1 \mathrm{~b}$ ) and recovered dolomites and limestones of proposed Cretaceous age (Aptian to Albian based on the occurrence of microfossils [Maync, 1973]). These rocks correlate with similar lithologies on land and can safely be assumed to be part of the backstop. More critically, DSDP Site 377 near the Cleft Basin recovered smectitebearing turbidites of African provenance and middle Miocene age [Hsü et al., 1978]. From the overlap of the various biostratigraphic zones found in these flysch-type sediments, Kastens [1991] estimated the period of 14.4-15.2 Ma for their deposition. Hence the Cleft Basin area, which is located $\sim 55 \mathrm{~km}$ south of the Hellenic Trench (Figure 2), was already seaward of the deformation front during midMiocene time. Given a plate motion of $10 \mathrm{~mm} \mathrm{yr}^{-1}$ between Africa and Eurasia, $55 \mathrm{~km}$ correspond to $5.5 \mathrm{Myr}$ (i.e., $\left.55 \mathrm{~km}(10 \mathrm{~mm})^{-1} \mathrm{yr}^{-1}\right)$. If these $5.5 \mathrm{Myr}$ are added to 14.4-15.2 Ma (see above and Kastens [1991]), accretion is suggested to start around $20 \mathrm{Ma}$. This value is in good agreement with the wealth of onshore evidence inferred from exhumation dynamics (see section 2.1 and Thomson et al. [1998, 1999]). It is unclear to us why Kastens [1991], on one hand, accepts the mid-Miocene time bracket for the flysch deposition (and, consequently, the vicinity to the African continental shelf) but then keeps arguing against an onset of accretion in the early Miocene. Instead, she refers to the isotopic evidence from calc-alkaline volcanic deposits of the Aegean (23.6-33 Ma [Fytikas et al., 1984]) and uses the older end to conclude accretion must have started as early as $33 \mathrm{Ma}$. We feel that this estimate is not reflected by the combined data available. Similarly, estimates for the initiation of accretion between 5-10 Ma [MacKenzie, 1978] and $13 \mathrm{Ma}$ [Le Pichon and Angelier, 1979] are in conflict with constraints from drilling (e.g., Site 377; see above) and the overall width of the prism. In summary, evidence compiled from published studies is in favor of an initiation of MedRidge accretion at $\sim 19$ Ma.

\subsection{Plate Kinematic Rates, Stress Directions, and Limiting Constraints}

[19] The eastern Mediterranean's Ionian and Levantine Basins are possible relics of the Mesozoic oceanic Tethys in the strictest sense, which have been preserved despite Alpine orogenesis [e.g., Hsü and Bernoulli, 1978]. By contrast, the Aegean Sea back-arc basin is postcollisionary. Constraints for a kinematic reconstruction have been collected from numerous earlier studies (see Table 1a), particularly, Le Pichon et al. [1982, 1995], Dercourt et al. [1986], DeMets et al. [1990], and Kastens [1991]. The variation of convergence rate with time is crucial for the determination of the length of the sedimentary input which has passed the deformation front during the time window chosen for the 
EPM $1-10 \quad$ KOPF ET AL:: MASS BALANCE ACROSS THE MEDITERRANEAN RIDGE

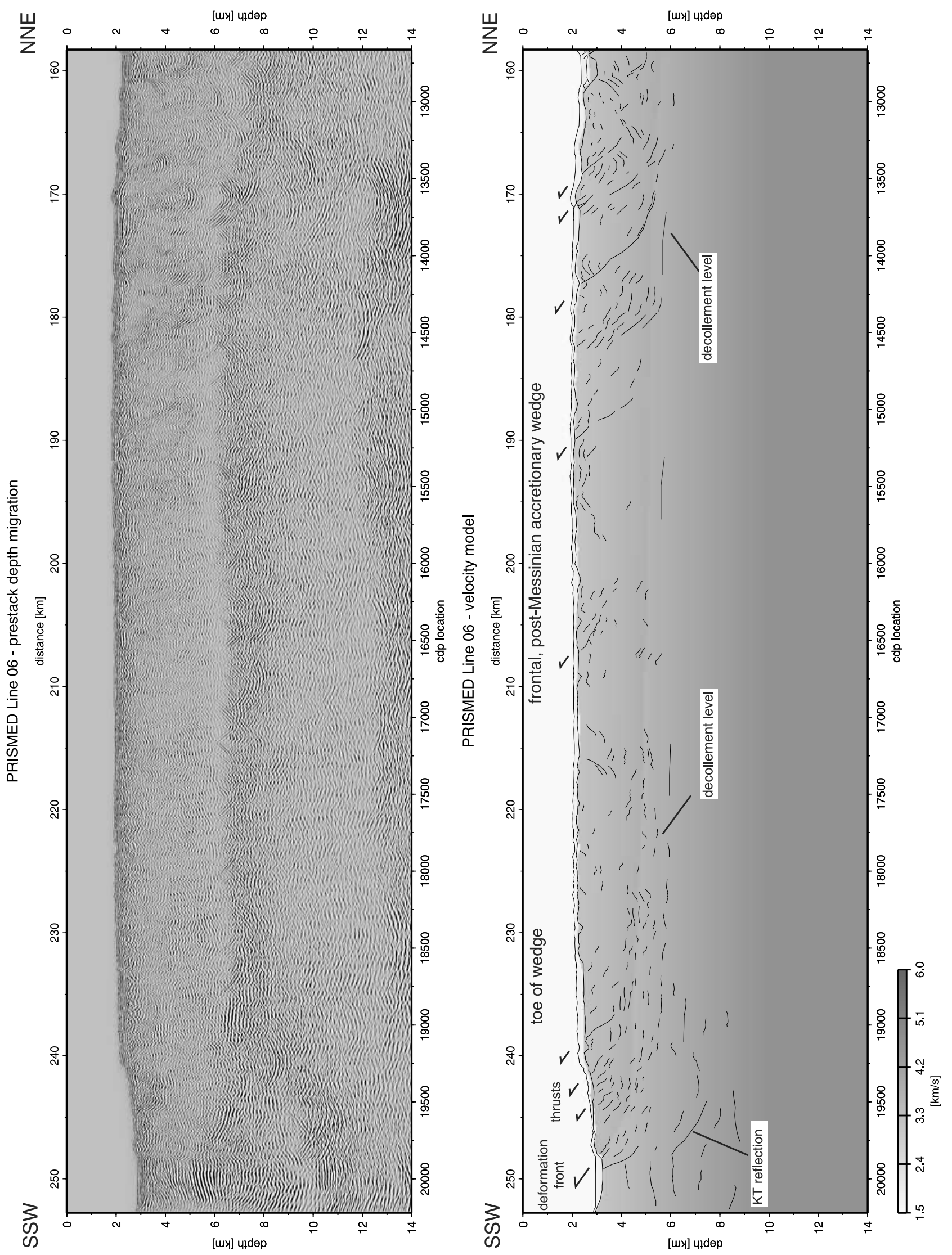


balance study. In the eastern Mediterranean, three major events control the plate kinematic rates: the onset of accretion, the initiation of Aegean back-arc spreading, and the collision of the Cyrenaica Promontory (Libya) with the toe of the MedRidge.

[20] The first aspect has already been discussed (section 2.1), and we accept $19 \mathrm{Ma}$ as the most likely estimate for exhumed HP/LT rocks to operate as an abutment. Hence only seafloor (and its sedimentary cover) which passed the MedRidge deformation front during the previous $19 \mathrm{Myr}$ will be regarded in our balance calculation. The main argument for this pin line is the assumption that exhumation of two HP/LT units of several km thickness must have been highly destructive to the Hellenic forearc 19 Ma. Even if an accretionary wedge may have been accumulated prior to that date (i.e., offscraped Oligocene strata from Pindos ocean floor), such a wedge was either torn to depth when the carbonate platform collided, or it found itself arcward of the carbonates (Plattenkalk after exhumation). Either scenario is unlikely to preserve an imbricate thrust wedge of considerable size. Also, the lack of any material older than Miocene in the samples recovered during previous DSDP and ODP drilling and other expeditions indirectly supports the assumption that the accretionary complex started to form as a consequence of the exhumed backstop.

[21] The beginning of back-arc spreading in the Aegean Sea has been dated to $13 \mathrm{Ma}$ [e.g., Le Pichon and Angelier, 1979]. This necessarily resulted in a change in net convergence rate, because half the Aegean spreading rate has to be added to the slow rate between Africa and stable Eurasia (10 $\mathrm{mm} \mathrm{yr}^{-1}$ [e.g., Dewey et al., 1973]). A net rate of 30-40 $\mathrm{mm} \mathrm{yr}^{-1}$ resulted from $13 \mathrm{Ma}$ onward [e.g., Le Pichon et al., 1995], so that we used the average $35 \mathrm{~mm} \mathrm{yr}^{-1}$ for the seafloor extension in our input models (see below). The Aegean spreading also caused break up of the previously continuous orogenic belt across Greece into western Turkey. This series of Paleocene and early Miocene nappe stacks of the northern forearc (i.e., the upper and lower nappes, see above, and Bonneau [1984]) was broken up by the extensional forces, and from the slivers of the outer forearc, only Crete remained in a position above sea level (Figure 1).

[22] As for the third issue, Le Pichon et al. [1995] have argued that the impact of the northward protruding Cyrenaica Promontory of the African Plate's leading edge with the toe of the ridge may have slowed down the convergence rate around 3-6 Ma. We feel that this assumption is not well supported, and instead propose that the collision may have caused a retardation (or even stillstand) in outward growth of the wedge some time during the Plio-Quaternary, mainly because all sediment-covered seafloor had been underthrust a while ago. Nevertheless, seismic images do not provide evidence for severe deformation of the wedge, and no apparent deformation of the downgoing Libyan margin, to indicate decrease in convergence rate. Instead, the seismic profile (Figure 4) indicates that the narrowing of the Mediterranean Basin due to incipient convergence is compensated for by both thrusting (in the south) and back- thrusting (in the north) of the wedge over the respective continental margins (see section 4.2).

\subsection{Sediment Accumulation Rates}

[23] The majority of the sedimentation rate information for this balance has been collated from reports of previous DSDP and ODP cruises. DSDP Legs 13 [Ryan et al., 1973] and 42 [Montadert et al., 1978] and ODP Leg 160 [Emeis et al., 1996] focused on both tectonic and paleoceanographic targets in the eastern Mediterranean Sea. In general, biostratigraphy is used to estimate sediment accumulation rates from the species recovered by coring. The wealth of information can be evaluated in the above mentioned reports, but a list of information relevant for this study is presented in Table $1 \mathrm{~b}$. The core-based sedimentation rate estimates cover a range from Burdighalian (lower Miocene) to present. As a consequence, it was necessary to estimate the Oligocene, Eocene, and Paleocene sedimentation rates, because sediment of that age had been deposited on the seafloor which later underwent subduction during the period regarded in this study (i.e., $19 \mathrm{Ma}$ to present). Owing to the lack of evidence from drilling, the depth-migrated seismic sections were interpreted to obtain a rate for the lower Tertiary intervals. Given that both the base of the Messinian evaporites and the KT boundary (Cretaceous/Tertiary) appear on seismic lines of the area as characteristic reflections [Ben-Avraham et al., 1995], we used the thickness between these two prominent reflections to estimate a "steady state" sedimentation rate from 5 to $65 \mathrm{Ma}$. The resulting rate of $41 \mathrm{~mm} \mathrm{yr}^{-1}$ (= mean average rate from a total of 3 estimates along each seismic profile) is very similar to that derived from drill core information (mean average from the Serravalian, Langhian, and Burdighalian rates is $45 \mathrm{~mm} \mathrm{yr}^{-1}$; see Table $1 \mathrm{~b}$ ), so that we are confident that the inferred rate is realistic. The sedimentation rates served to build the reconstructed input model.

\subsection{Porosity-Depth Relationship From ODP Drilling Data}

[24] ODP Leg 160 focused on the central accretionary wedge in the Olimpi field mud volcano area south of Crete (Sites 969-971) and the toe area farther toward the Sirte abyssal plain (Sites 972-973). At Site 969, a Plio-Quaternary succession of nannofossil oozes and clays with interbedded ash layers, sapropels, and silts were penetrated in 4 holes. The same hemipelagites were found interbedded with mud debris flow deposits when drilling nine holes into mud volcanoes and their surrounding subseafloor at Sites 970 and 971 [Robertson and Shipboard Scientific Party ODP Leg 160, 1996]. Farther northwest, Sites 972 and 973 drilled the uppermost sediments accreted from the Ionian abyssal plain, now forming the toe area of the wedge [Emeis et al., 1996]. The Pleistocene nannofossil clays are often interfingered with turbidite deposits, the latter of which also account for a local increase in sediment accumulation rate (up to $111 \mathrm{~m} \mathrm{Myr}^{-1}$ [Emeis et al., 1996]). In summary, we are confident that the lithologies of the sites chosen well

Figure 3. (opposite) (top) SSW-NNE oriented, prestack depth-migrated PRISMED seismic line 6 across the accretionary wedge, being significantly less wide than line 3 farther west. (bottom) Structural line drawing overlying the 2-D velocity model. 
EPM $1-12$ KOPF ET AL.: MASS BALANCE ACROSS THE MEDITERRANEAN RIDGE

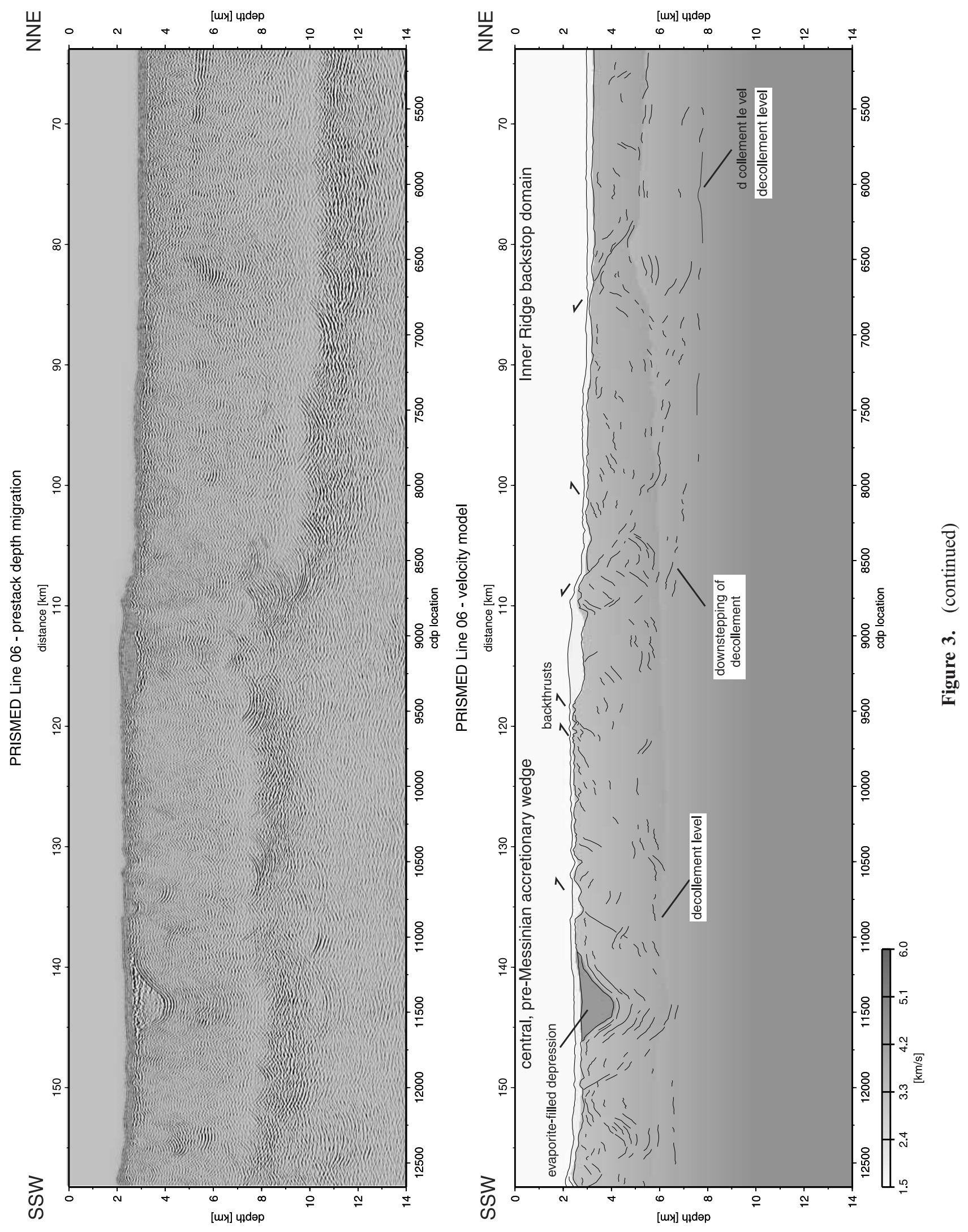




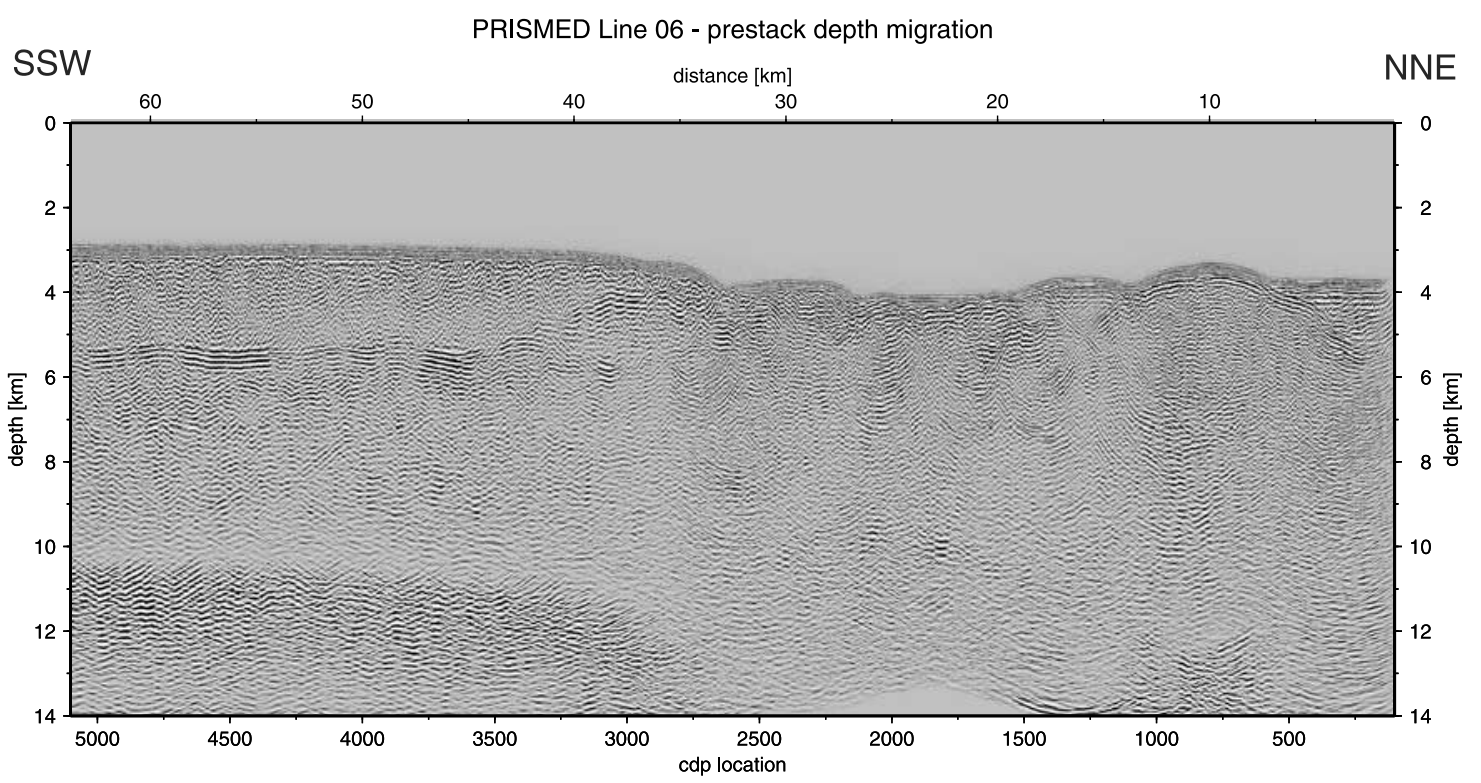

PRISMED Line 06 - velocity model

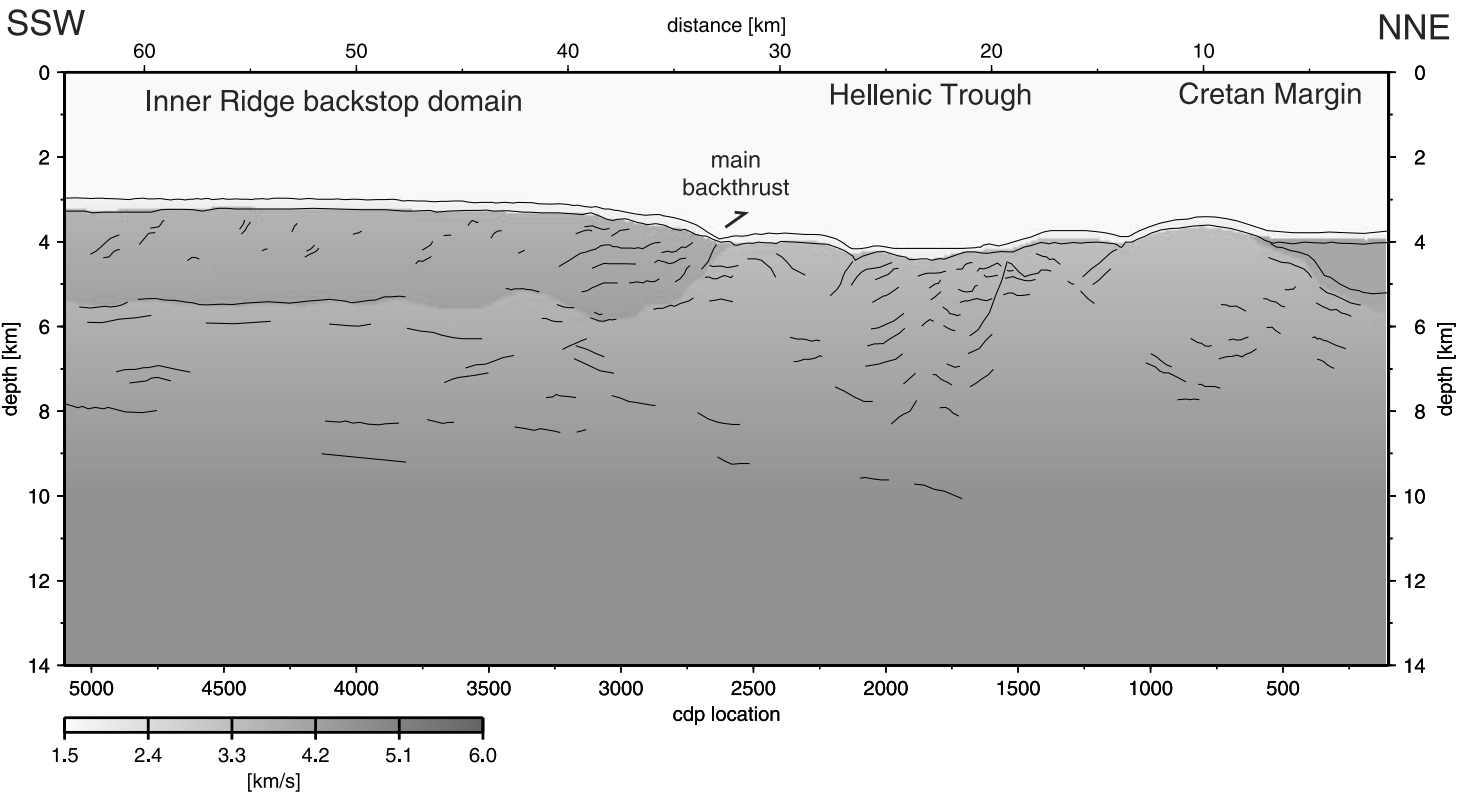

Figure 3. (continued)

represent modern marine sediments of the subduction zone in the eastern Mediterranean.

[25] In general, porosities of granular sediments are reduced with increasing depth of the overburden, following an exponential relationship [e.g., Athy, 1930]. The higher the fine-grained (i.e., clay) component, the more dramatic is the loss of pore volume in the upper 10s of meters (see review by Moon and Hurst [1984]). For the muds and mudstones recovered from MedRidge drilling (Sites 969973 , Figure $1 \mathrm{~b}$ ), the terminal drilling depth of $\sim 200 \mathrm{~m}$ below seafloor (mbsf) of the various holes prevent derivation of a porosity-depth relationship for greater depths. Hence porosity data from the accretionary wedges off southern Chile [Behrmann et al., 1992] and SW Japan [Taira et al., 1991] were included to constrain depths of
200-1000 mbsf (Figure 7). On the basis of the best fit porosity-depth relationship (calculated for the data set in Figure 7 [Athy, 1930]), the distinction between the solid and fluid portion of the area of the accretionary prism along each depth-migrated profile (Figures $2-5$ ) as well as the basin wedges (Figures $8 \mathrm{a}$ and $8 \mathrm{~b}$ ) was carried out.

\section{Description of Seismic Profiles}

[26] As a result of some of the data already having been published after preliminary processing [Chaumillon, 1995; Chaumillon et al., 1996; Chaumillon and Mascle, 1997], we restrict our descriptions to the main observations and add detail only when necessary with respect to this balance study. Particular attention will be drawn to the 
EPM $1-14$ KOPF ET AL:: MASS BALANCE ACROSS THE MEDITERRANEAN RIDGE

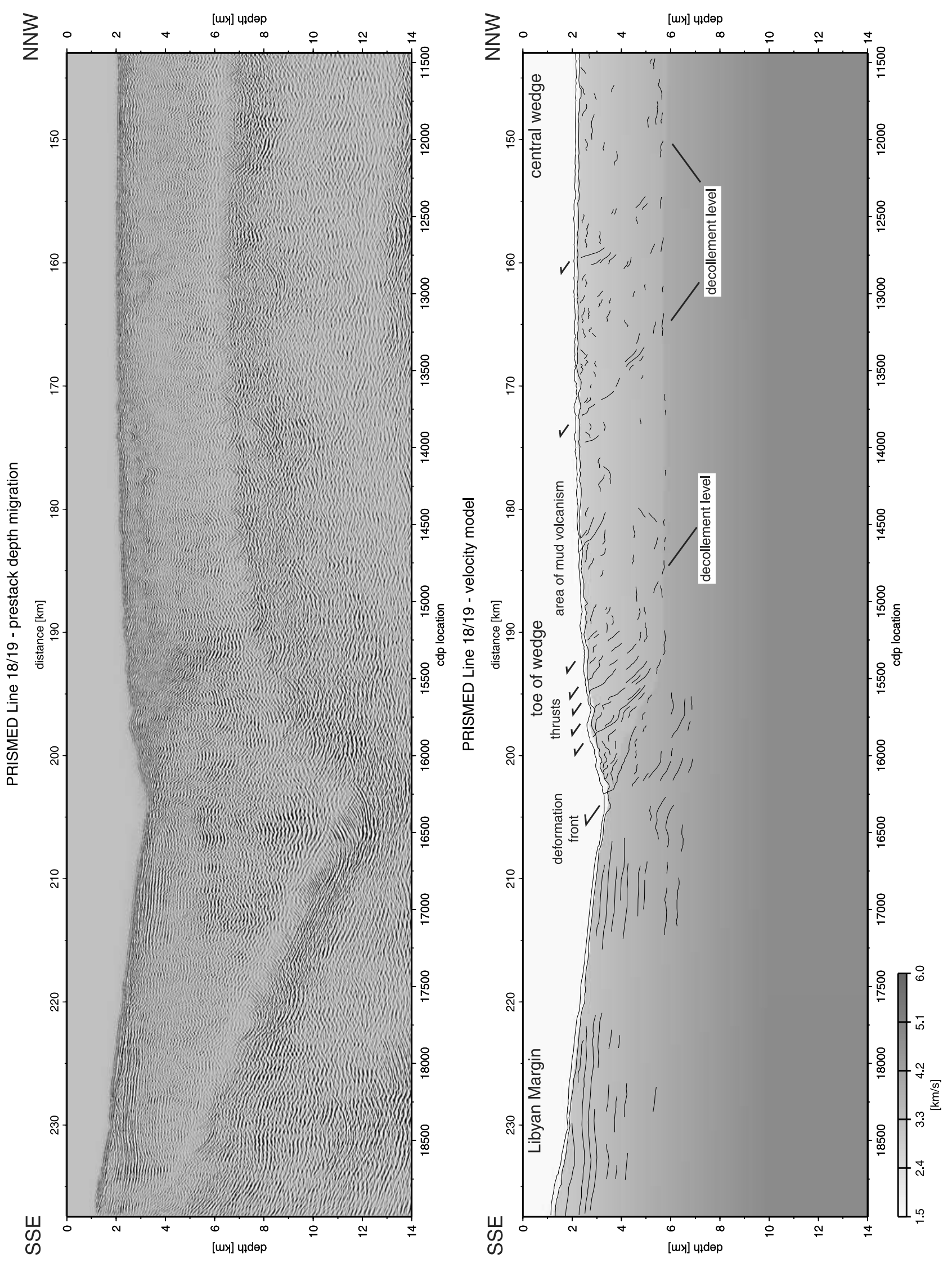


identification of the deformation front, the plate boundary at greater depth, and the apex of the prism when meeting the backstop.

\subsection{Western Part (Sirte)}

[27] The western branch of the MedRidge accretionary wedge has been off scraped from sediments traveling on the Sirte abyssal plain in the southern Ionian Basin (Figure 1). It is represented by lines 3 and 6 (Figures 2 and 3), which were both acquired in a rough SW-NE direction, but nonetheless show a number of differences concerning width of the prism, style of deformation, or geometry of its frontal portion (the protothrust zone).

[28] The westernmost profile, line 3, shows an almost $340 \mathrm{~km}$ wide wedge with an increasing thickness toward the backstop (Figure 2). The incoming sedimentary sequence is at least $6 \mathrm{~km}$ thick, and is already affected by outward growth of the frontal thrust in its upper portion. A seaward vergent frontal thrust separates the flat, superficially undeformed seafloor sediment from the slightly folded and faulted accreted toe from approximately $26 \mathrm{~km}$ (CDP 2200 , Figure 2) to the north. However, the protothrust zone from $\sim 5-24 \mathrm{~km}$ (CDP 350-2200) is characterized by landward vergent faults which intersect the uppermost $1.5 \mathrm{~km}$ below the seafloor. Such a phenomenon has been described elsewhere (e.g., along the Cascadia margin off Washington [Flueh et al., 1998]) and has previously been related to rapidly deposited, overpressured sedimentary successions. Alternatively, discontinuous evaporite deposition during the Messinian may act as a lubricant and this way cause a change in vergence. The landward vergent slice of sediment is thrust beneath the toe of the wedge, and may be underplated in the near future. The part of the toe from about 26 to $105 \mathrm{~km}$ (CDP 2200-8400) is interpreted as post-Messinian wedge (Figure 2 and Reston et al. [2002, Figure 5]). Its landward contact to pre-Messinian accreted strata is a landward vergent feature, possibly a backthrust fault. This interpretation and the geometry of the contact between the two accreted blocks is in accordance with Reston et al. [2002], but in conflict with Chaumillon and Mascle [1997]. On the basis of a time-migrated section, the latter workers interpret the frontal $140 \mathrm{~km}$ as post-Messinian rock, which has been imbricated as a series of seaward vergent slices. Our new evidence after reprocessing the data suggests that the seaward vergent "duplexes" seen are overridden by the post-Messinian wedge along the backthrust feature; hence, the duplexes themselves are the outermost portion of the pre-Messinian wedge [see also Reston et al., 2002, Figure 7]. Farther landward, a continuous increase in décollement depth is seen. While the toe area has an initial thickness of $1.5-2 \mathrm{~km}$, the plate boundary is located at almost $4 \mathrm{~km}$ bsf at about $120 \mathrm{~km}$ behind the deformation front, where a small downward step of the décollement is inferred. A second of these steps to a depth of $>5 \mathrm{~km}$ bsf occurs at $200 \mathrm{~km}$ (Figure 2), suggesting that the central part of the accretionary complex is dominated by seaward verging thrusts. In fact, conjugate faulting is seen as well, but backthrusting becomes of increasing importance toward the apex of the prism onto the Inner Ridge (the latter extending from approximately 285 to $342 \mathrm{~km}$, CDP 22700 27400). On the Inner Ridge, the Cleft Basin and Hellenic Trough (311-342 km, CDP 24800-27400, Figure 2) occur adjacent to the Cretan Margin. The area north of the Cleft Basin, where $P$ wave velocities increase continuously, is thrust backward upon the gently southward dipping leading edge of the forearc basement. We have carefully analyzed the subsurface data of the backstop domain with its northward dipping units and observe higher velocities north of the Hellenic Trough compared to the south. These highvelocity units are probably limestones and other nappes of the outer Hellenides, while the material north of the Cleft Basin represents ancient accreted, well-consolidated rock from the earliest period of accretion (19 Ma). These firm accreted sediments are backthrust over the forearc basement, and hence suffer more intense dewatering than the central part of the wedge. Their base relative to the forearc continental basement is not clearly imaged, but possibly dips from $8 \mathrm{~km}$ below sea level (bsl) beneath the Hellenic Trench to some 11-12 km bsl beneath the Cleft Basin (Figure 2b). In this area, we infer the outermost edge of the continental plate, beneath which African crust and sediments are subducting.

[29] In general, a number of similarities exist between line 3 and its eastward neighbor, line 6 (Figure 3). First, the stepping downward behavior of the décollement is also found here, with the major deepening at $\sim 165 \mathrm{~km}$ (CDP 13300) and between 110 and $90 \mathrm{~km}$ (CDP 88007100; Figure 3). The leading edge of the continental backstop dips seaward and extends to $\sim 32 \mathrm{~km}$ (CDP 2600), and is separated from the Inner Ridge of the MedRidge by backthrust faults. Apart from the similarities, profound differences exist between lines 3 and 6 . First, the width of the prism is considerably reduced to only $220 \mathrm{~km}$. Second, the accreted material of the prism is overlain (rather than underthrust) by Messinian evaporites, as can be seen from the depression between 137 and $146 \mathrm{~km}$ (CDP 1110011750; Figure 3). Consequently, the accretionary wedge along line 6 had been uplifted already during the Messinian. No evidence for any clear post-Messinian frontal accretion can be observed on the seismic images. Third, a prominent southward dipping backthrust cuts through the Inner Ridge and crops out on the seafloor at $\sim 32 \mathrm{~km}$ (CDP 2600, Figure 3a). It represents the boundary between highly compacted ancient accreted sediments on top and less dewatered strata below, as is evidenced from the slight velocity inversion (Figure 3b). Such an inversion has not been observed on line 3 , and suggests that overpressured (possibly younger) material underlies the entire wedge along line 6. Fourth, the overall seafloor morphology is rougher along line 6 , which is mirrored by more intense faulting. In summary, the differences can be attributed to the more accentuated collision and shortening toward the east. The proximity to the shelf is reflected by the already deformed sediment between the Libyan Margin and the toe

Figure 4. (opposite) (top) SSE-NNW oriented, prestack depth-migrated PRISMED seismic line 18/19 across the accretionary wedge, with the central part being backthrust onto the Inner Ridge to the north. Mud volcanism is abundant along these backthrust out-of-sequence faults. (bottom) Structural line drawing overlying the 2-D velocity model. 
EPM $1-16$ KOPF ET AL.: MASS BALANCE ACROSS THE MEDITERRANEAN RIDGE
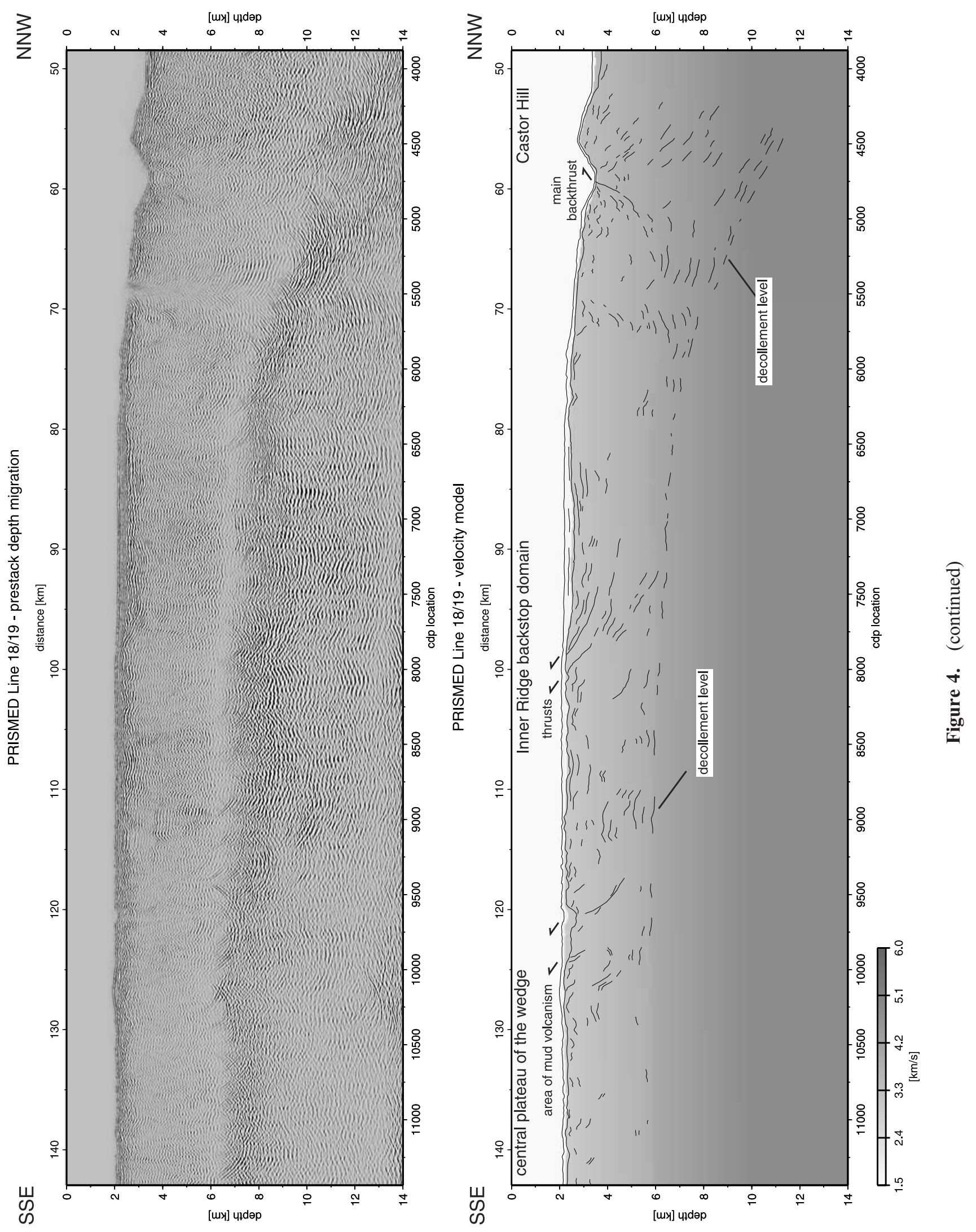


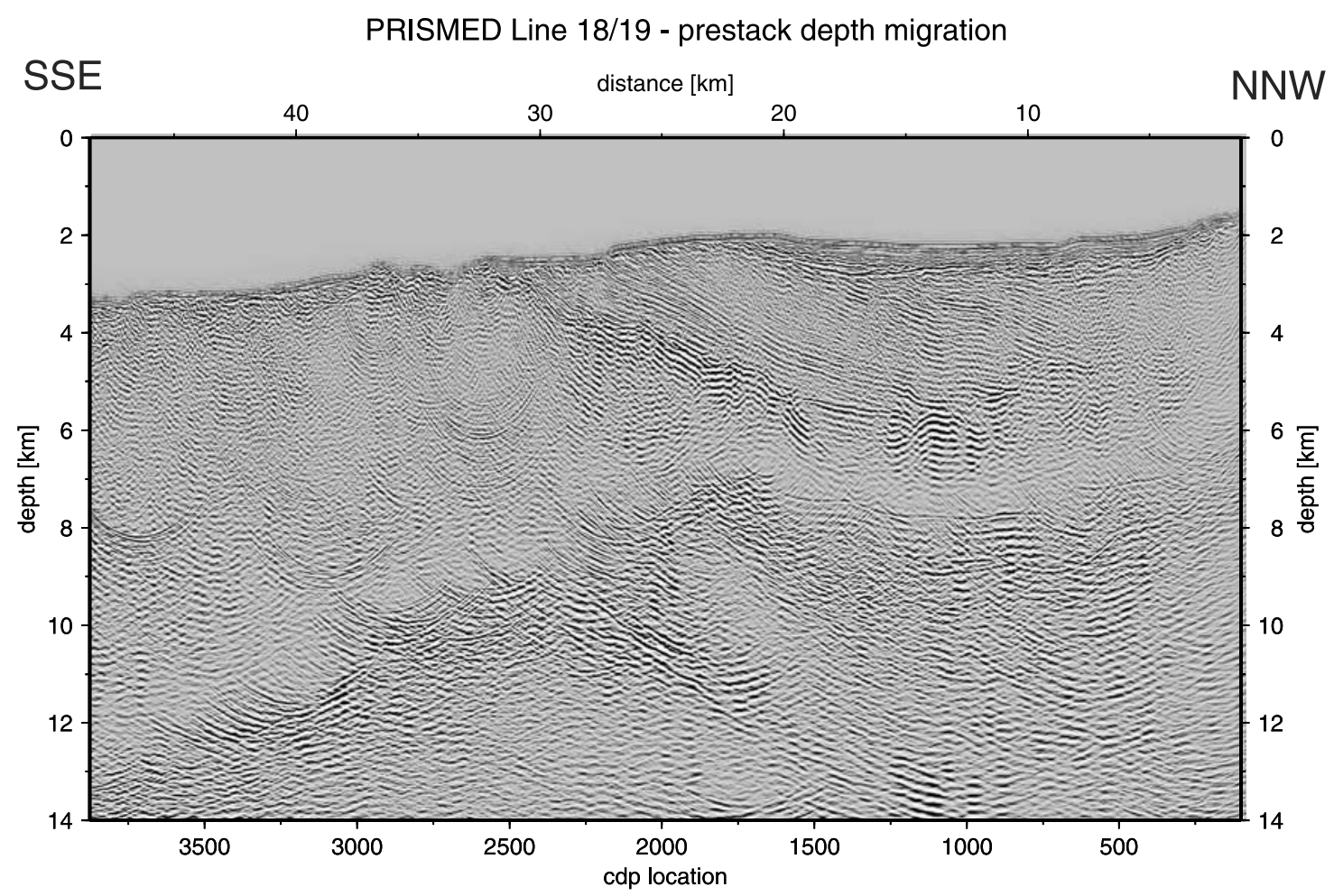

PRISMED Line 18/19 - velocity model

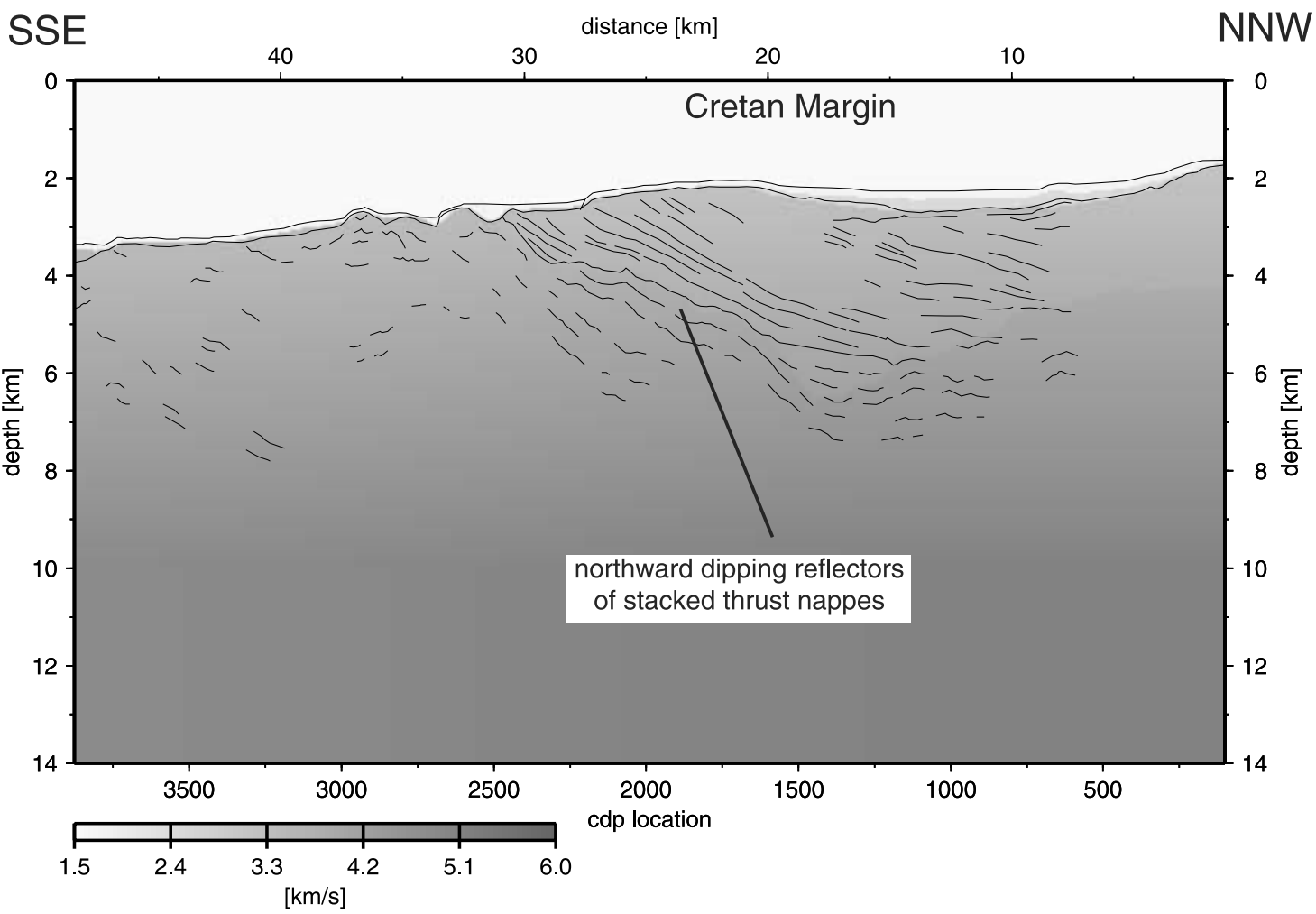

Figure 4. (continued)

of the wedge (around 242-249 km, CDP 19250-20000, Figure 3). Here, the bright reflectors of Lower Tertiary sediments show some downward bending and gentle folding. Assuming that the indenting Cyrenaica Peninsula may already affect the entire area along which line 6 is located (Figure 1), the protruding African Shelf at depth may force some sediment into subduction, or underplating. This would not only explain the higher amount of tectonic shortening, but also the inversion in $P$ wave velocity along the entire wedge (and most profoundly in its distal part). 
EPM $1-18$ KOPF ET AL.: MASS BALANCE ACROSS THE MEDITERRANEAN RIDGE
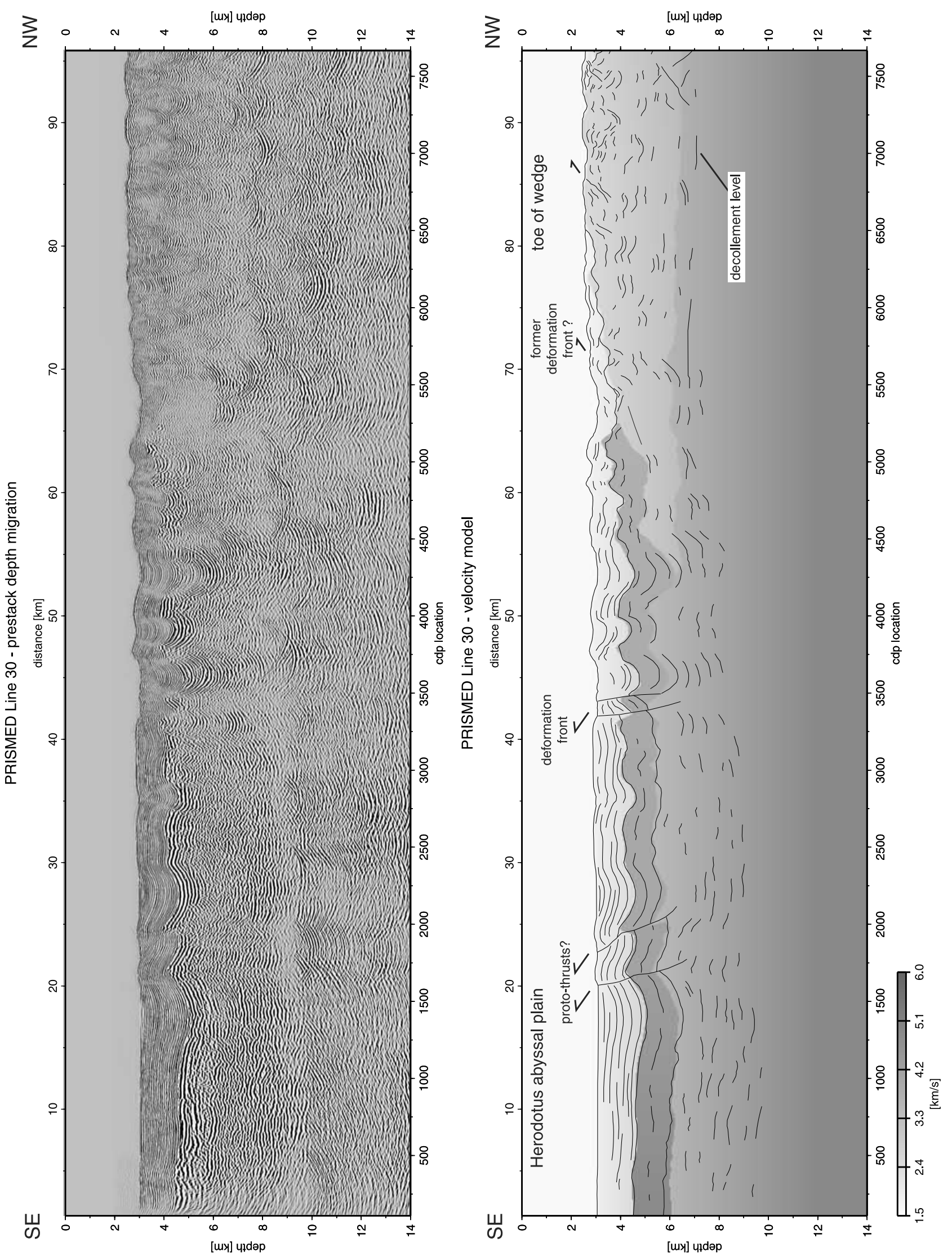
The velocity inversion as well as the reduced total width of the prism are probably related to underthrusting rather than frontal accretion since 5-6 Ma, aided by evaporitebearing incoming sediments. Such a hypothesis stands in a line of reasoning with the decrease in outward growth rate of the wedge since the Messinian [Kastens, 1991]. We will pick up this aspect when discussing the results from the balance of subduction versus accretion (section 5).

\subsection{Central Collision Zone}

[30] Along line 18/19 north of the Cyrenaica Promontory, the gently northward dipping, indenting Libyan margin is well imaged between 203 and $237 \mathrm{~km}$ (CDP 16200-19000, Figure 4). All ocean floor of the incoming plate has already been consumed and incorporated into subduction-accretion. The accretionary prism has a width of only $145 \mathrm{~km}$, which is less than half of that along line 3 . However, no significant enhancement in $P$ wave velocities is seen within the accreted rocks if compared to lines 3 or 6 (Figure $4 \mathrm{~b}$ ). This suggests that instead of more intense lateral compaction due to being clamped between Libya and Crete, uplift and backthrusting compensated for the lateral stresses. As a result, the water depth of the Mediterranean Ridge is often less than $2 \mathrm{~km}$ along the central parts of line 18/19. The elevation also suggests that, similar to line 6 (see above), the wedge had been a topographic high prior to Messinian dessication. Consequently, a distinction between pre- and post-Messinian accretion is impossible. Instead, indurated layered rock from the Libyan margin is underthrust the pre-Messinian wedge, resulting in a step-like increase in $P$ wave velocity beneath the décollement. No evidence for unconsolidated Plio-Quaternary sediment is seen beneath the wedge, so that we conclude that all seafloor passed the deformation front prior to 4-5 Ma (early Pliocene). The accretionary wedge itself is characterized by predominantly reverse thrust faulting, although some conjugate faults are observed in the central plateau domain (100-130 km, CDP 8000-10400, Figure 4). This area shows abundant mud volcanoes of predominantly dome-shaped geometry (e.g., the Olimpi field mud volcano domain [see Camerlenghi et al., 1995]). Dips of the thrusts range between $6^{\circ}$ and $24^{\circ}$. The Inner Ridge, located south of Castor Hill at $\sim 59-76 \mathrm{~km}$ (CDP 4700-6000, Figure 4b), is only $\sim 60 \mathrm{~km}$ wide (CMP 4800-9600, Figure 4b). This suggests that even the material at the apex is affected by incipient collision in the area, causing transfer of material beneath the backstop. North of Castor Hill, a small forearc basin traps sediments from the Cretan Margin of presently $\sim 200 \mathrm{~m}$ thickness.

\subsection{Eastern Part (Herodotus)}

[31] The fourth profile studied, line 30, is oriented SENW and cuts a domain where subduction occurs at slightly oblique angles (see vector of convergence in Figure 1). The first measure expressing the less profound lateral compression is the width of the prism, varying from $160 \mathrm{~km}$ to $200 \mathrm{~km}$ (depending on the interpretation, Figure 5). A conservative interpretation assumes a landward vergent frontal thrust reaching the seafloor at $66 \mathrm{~km}$ (CDP 5400). By contrast, incorporation of the southernmost deformed sediments into the wedge would mean that a seaward vergent protothrust intersects sediments of more than $3 \mathrm{~km}$ thickness and reaches the seafloor at $20 \mathrm{~km}$ (CDP 1600, Figure 5). However, incorporating the outermost portion coincides with the interpretation of line 3 in the west. No matter which interpretation is favored, the width of the wedge along line 30 already exceeds that of line 18/19 in the central collision zone. In the south, thick, rapidly deposited sediments of the Nile fan travel on the Herodotus abyssal plain toward the toe of the wedge. As mentioned above, thick slices of these sediments are faulted in the protothrust zone (20-66 km, CDP 1600-5400, Figure 5), and are in the process of being frontally accreted. In fact, this imbricate slice, which extends northward to approximately $104 \mathrm{~km}$ (CDP 8300, at a depth of almost $7 \mathrm{~km}$, Figure 5b), may represent the evaporite-bearing, post-Messinian wedge. The crumpled, intensely deformed overlying material shows abundant reverse and backthrust faulting, and had very likely been accreted during pre-Messinian time. The actual accretionary wedge south of it can be divided in an outer zone of less intense deformation (20-66 km, CDP 1600-5400), a central, highly deformed part (66-136 km, CDP 5400$10850)$, and a less deformed inner part south of the apex (136-172 km, CDP 10850-13750, Figure 5). Wide mud extrusive features cover the prism [Kopf et al., 2001]. A welldeveloped forearc basin can be seen in the distal part of the wedge north of the mud pies, between the Pliny and Strabo "Trenches". The basin fill, located north of Strabo Seamount, shows thick evaporite precipitates, as evidenced from $P$ wave velocities exceeding $4.5 \mathrm{~km} \mathrm{~s}^{-1}$ (Figure 5b). The implication for the vertical tectonic movements of the area is that the apex of the prism has undergone recent strong uplift, because the salt must have been precipitated in a position well below the level of the central plateau of the wedge. The likely candidates along which upward thrusting has occurred are southward dipping backthrusts at dip angles around $20^{\circ}$. The clamped apex of the wedge apparently suffers transpressional stresses, and got elevated in the process of continuous oblique subduction in this region [Chaumillon and Mascle, 1997]. In addition, the Hellenic Trench (Pliny and Strabo branches, Figure 1b) shows thin layers of Messinian evaporites, indicative of a previously deeper position. This implies that the entire backstop area along line 30 has undergone strong tectonic uplift, possibly by tectonic underplating or collision of the leading edge of the African margin.

\section{Quantitative Estimates}

\subsection{Area and Volume Estimates}

\subsubsection{Incoming Sediment}

[32] The basin models for each of the seismic traverses were created as restored wedges in a coordinate system with age (i.e., time) versus thickness. The only complication to this two-dimensional (2-D) model is the necessity to

Figure 5. (opposite) (top) SSE-NNW oriented, prestack depth-migrated PRISMED seismic line 30 across the accretionary wedge, showing gentle folding and faulting at the toe, and large mud pies in the central domain. (bottom) Structural line drawing overlying the 2-D velocity model. 
EPM $1-20$ KOPF ET AL.: MASS BALANCE ACROSS THE MEDITERRANEAN RIDGE
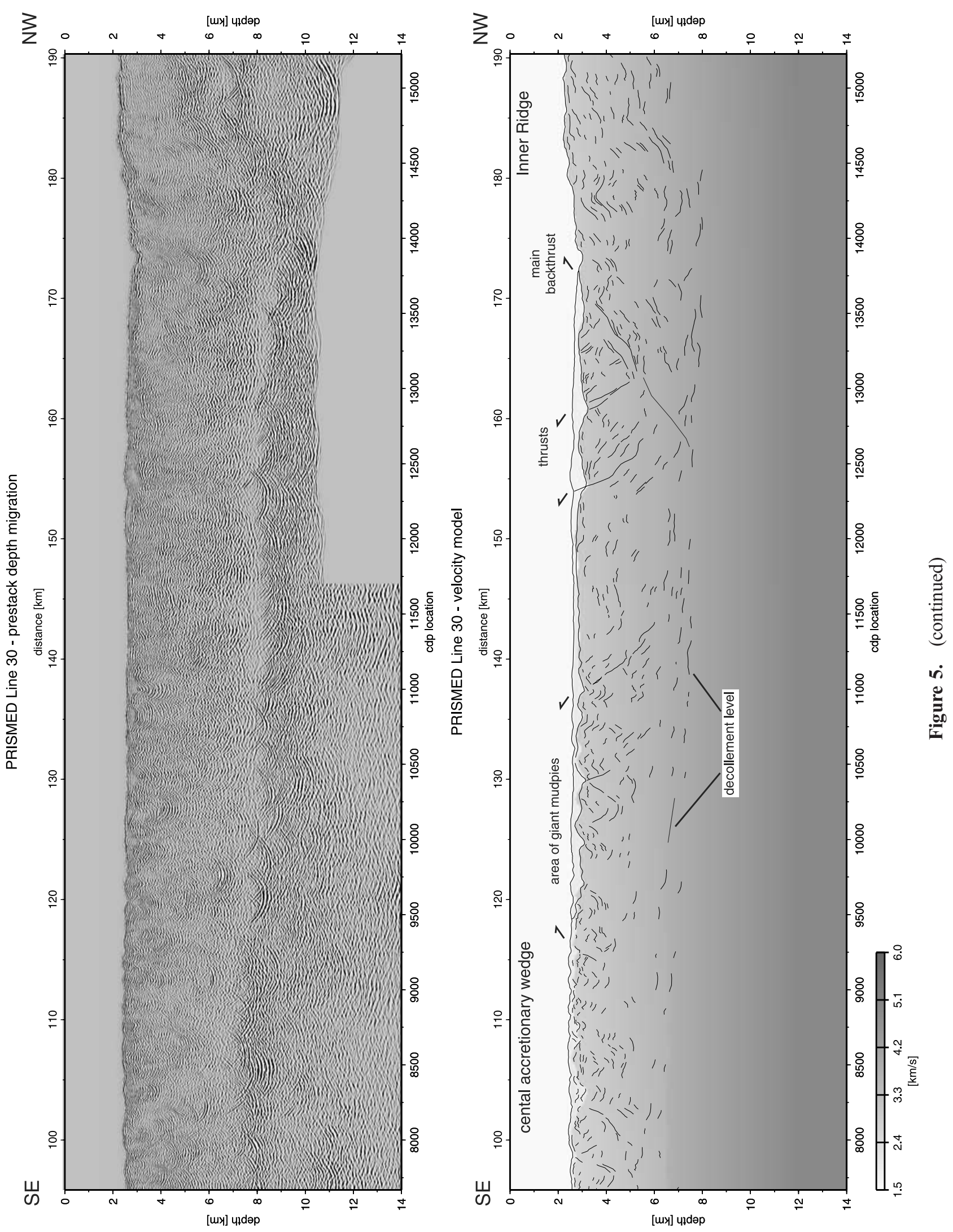


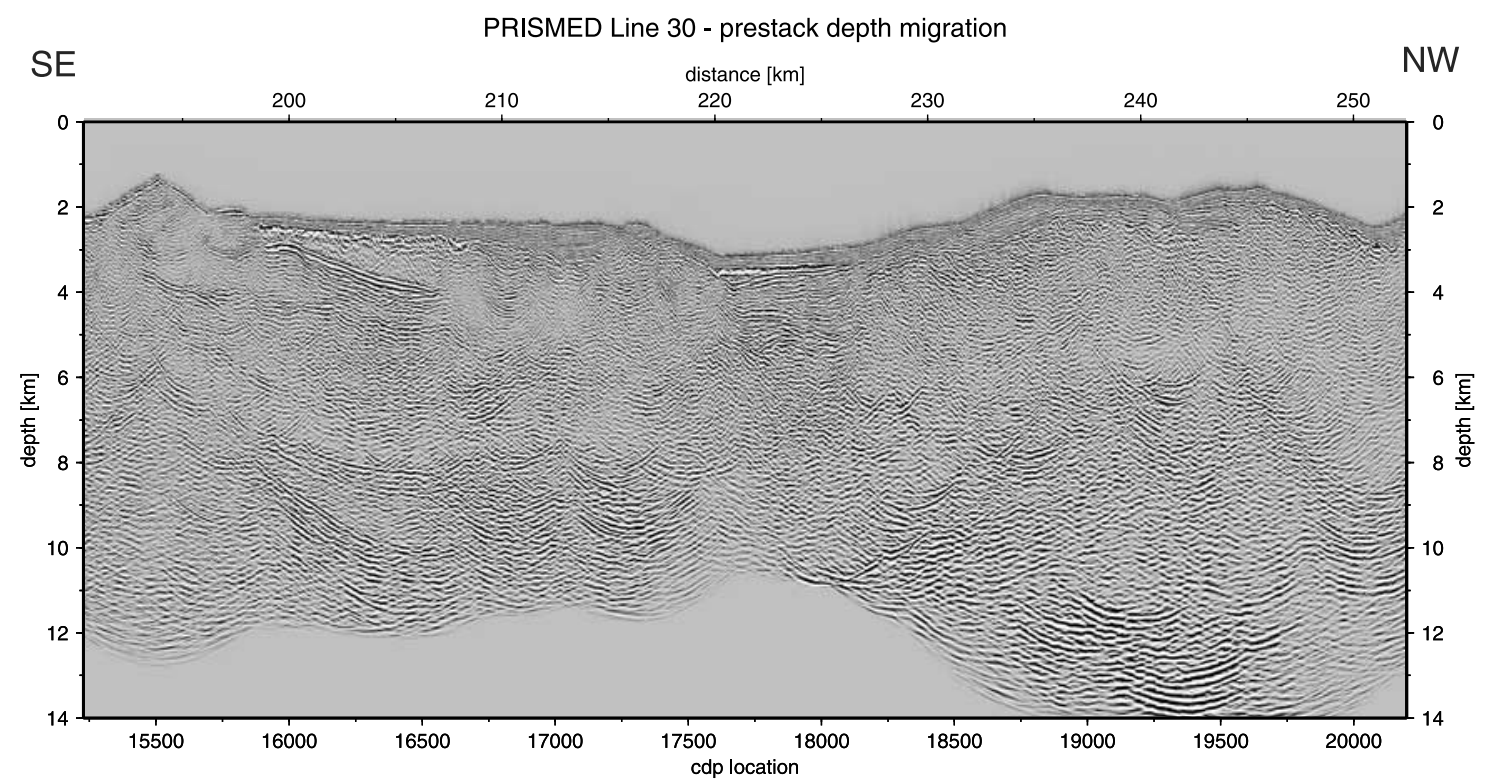

PRISMED Line 30 - velocity model

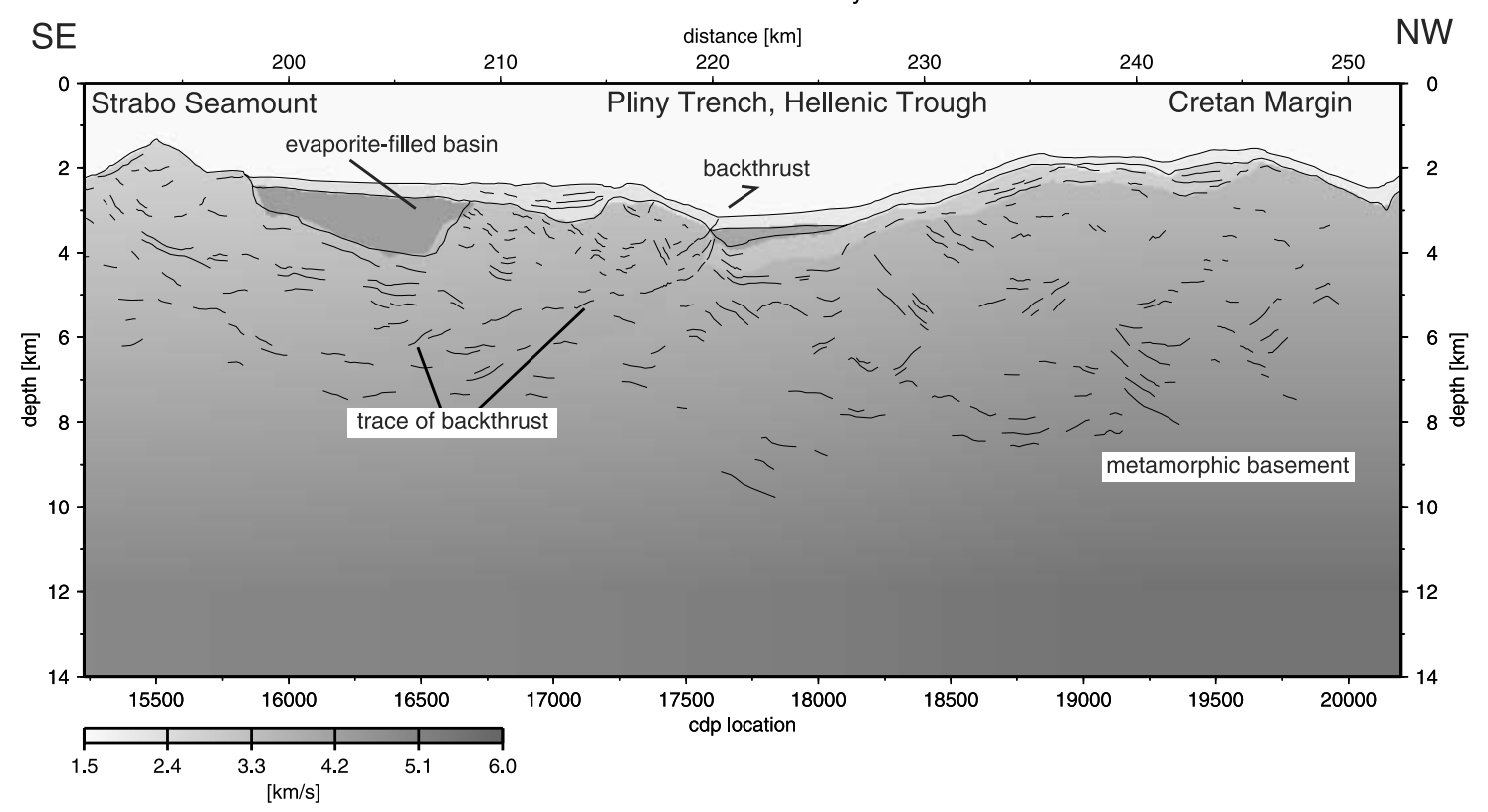

Figure 5. (continued)

account for the changes in plate convergence rate on the $x$ axis. In general, age (or time) is marked using the convergence rates of the incoming plate (Africa) relative to Eurasia. For reference, length is also given on a second $x$ axis, having its origin at the present-day deformation front (Figure 8). Hence the lower $x$ axis defines the position of the deformation front at any given time, while the length on the upper $x$ axis gives the corresponding width (i.e., how much sediment of the input wedge has already passed the deformation front). As has been discussed earlier, a change in net convergence rate occurred at 13 Ma because of onset of Aegean spreading; this change is accounted for (see upper $x$ axis, Figure 8). Similarly, the changes in sedimentation rates (see Table 1b) define the relative growth in thickness of the input wedge on the $y$ axis (Figure 8). As a result of the influence of the Nile deep-sea fan on sediment accumulation on the Herodotus abyssal plain (line 30 in the east, Figure 1a), we reconstructed models for two scenarios: One model with moderate Messinian and Plio-Quaternary rates was used for the balance estimates along lines 3, 6, and 18/19 (Figure 8a), while a second input model with enhanced sedimentation (from the Nile) during most recent Earth history was used when balancing along line 30 (Figure $8 \mathrm{~b}$ ).

[33] The area of the sedimentary prism in the model can be easily calculated using the cross sections (Figures $8 \mathrm{a}$ and $8 \mathrm{~b}$ ), and the results are given in Table 2 . To account for porosity changes with burial, each basin model is subdivided into different bodies of $1000 \mathrm{~m}$ thickness, for which porosity had been estimated using 20 increments per body (i.e., layers of $50 \mathrm{~m}$ thickness). The porosity function derived from ODP drill cores (Figure 7) was used to obtain an average porosity for each individual $50-\mathrm{m}$ layer as a 


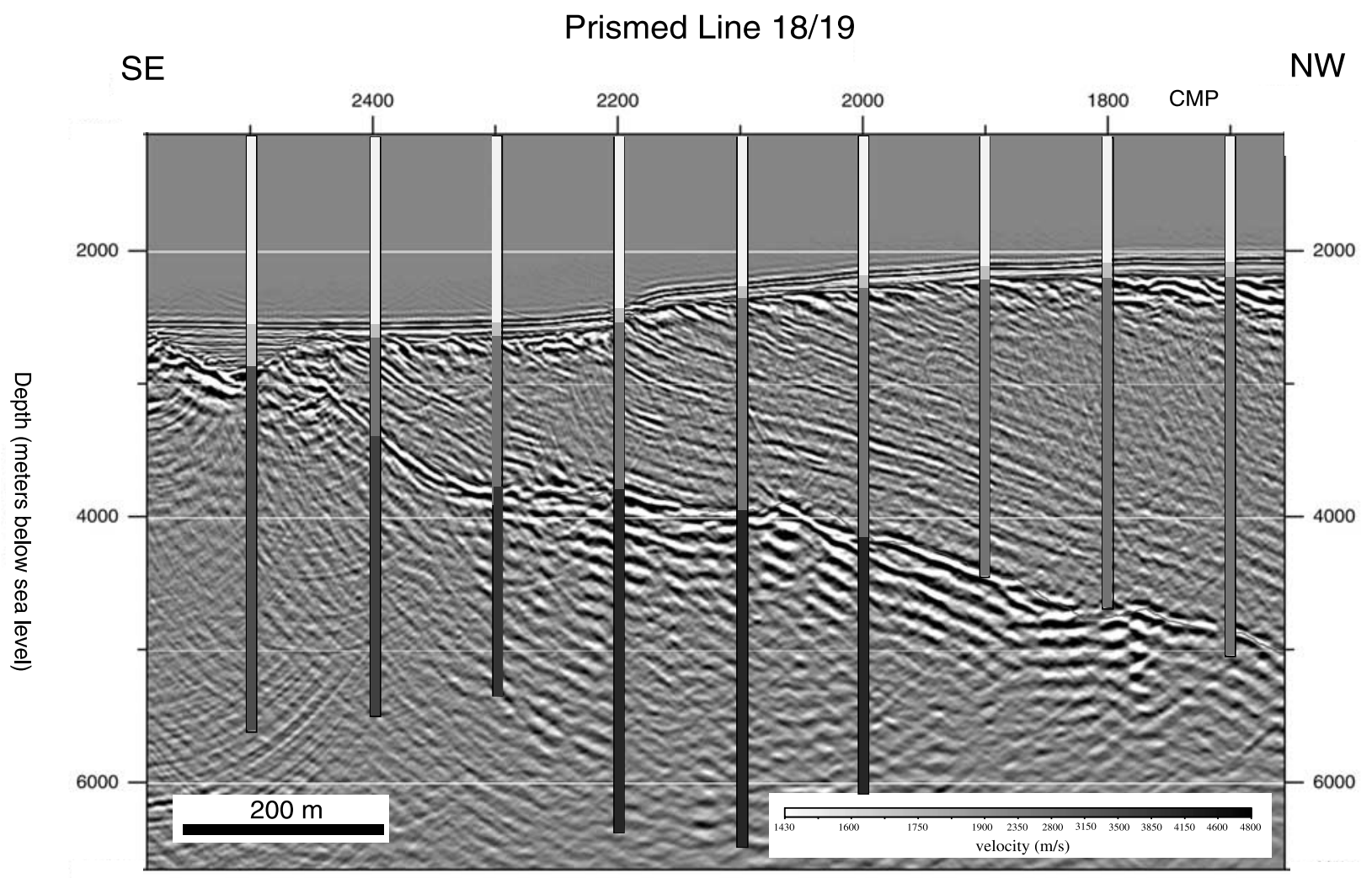

Figure 6. Sample seismic section across the backstop domain of line 18/19, south of Crete. Columns in rainbow shading illustrate the optimum velocity information gained from prestack depth migration using depth focusing analyses from "velocity scans". This part of the section was migrated with velocities ranging from 2100 to $4800 \mathrm{~m} \mathrm{~s}^{-1}$ (300 $\mathrm{m} \mathrm{s}^{-1}$ intervals); both velocities higher and lower than the ones shown resulted in blurred images and artificial curvature of events. See color version of this figure at back of this issue.

function of burial depth. The area occupied by fluid was then subtracted from the total area of each layer to get the area of the solid rock mass. Finally, the sum of the solid portion of all individual layers along each cross section was calculated. Along lines 3, 6, and 18/19, the total crosssectional area of the basin wedge (Figure $8 \mathrm{a}$ ) is $1266 \mathrm{~km}^{2}$, and contains approximately $820 \mathrm{~km}^{2}$ of solid rock (Table 2). Along line 30 with higher sedimentation rates, the total input wedge (Figure $8 \mathrm{~b}$ ) of $1747.5 \mathrm{~km}^{2}$ comprises of $1192.5 \mathrm{~km}^{2}$ of solid material. These solid portions were used for the balance against the accreted material (see below). If each seismic profile is envisaged as representative for a 1-km-wide slice along strike in the synthetic basin, the estimated areas become volumes (i.e., $820 \mathrm{~km}^{3}$ and $1192.5 \mathrm{~km}^{3}$ of solid material per kilometer of trench width for the two models shown in Figure 8).

\subsubsection{Accreted Sediment}

[34] The area of the accreted wedge along each profile, as interpreted on the depth-migrated seismic section, was calculated as layers of $1000 \mathrm{~m}$ thickness relative to the seafloor. Like for the basin models, the different layers of the accretionary wedge were then divided into their fluid and solid portions using the porosity-depth relationship established earlier (see above; Figure 7). The total areas of bulk accreted material show a strong variation along strike. From west to east, the total accreted area decreases from $\sim 670 \mathrm{~km}^{2}$ (line 3) and $460 \mathrm{~km}^{2}$ (line 6) to only $240 \mathrm{~km}^{2}$ in the central collision zone (line 18/19), before increasing in the east to $\sim 400 \mathrm{~km}^{2}$ due to accumulation of Nile sediments (line 30). After having subtracted the area of the pore fluid, solid rock mass occupies approximately $485 \mathrm{~km}^{2}$ (line 3), $330 \mathrm{~km}^{2}$ (line 6), $165 \mathrm{~km}^{2}$ (line 18/19), and $290 \mathrm{~km}^{2}$ (line 30). This means that compared to line $18 / 19$ in the central collision zone, almost twice as much solid rock has been accumulated along the neighboring profiles in the east (line 30) and west (line 6). Note that along the westernmost line 3 , the solid rock area is three times that of the central collision zone south of Crete.

[35] The full range of results for bulk, solid, and fluid area are presented in Table 3. As for the basin models, the third

Table 1a. Plate Kinematic Rates for the Eastern Mediterranean Subduction Zone

\begin{tabular}{ll}
\hline \multicolumn{1}{c}{ Reference } & \multicolumn{1}{c}{ Rate of Convergence, $\mathrm{mm} \mathrm{yr}^{-1}$} \\
\hline Le Pichon et al. [1995] & 30 (or even 40 since 13 Ma) \\
Argus et al. $[1989]$ & 10 (prior to $13 \mathrm{Ma})$ \\
Le Pichon et al. $[1982]$ & 40 \\
Jongsma [1987] & 70 \\
Jongsma et al. $[1987]$ & 10 (66 including strike slip) \\
Kastens [1991] & 20 (higher pre-Messinian rate inferred) \\
Chase [1978] & 38 \\
Minster and Jordan [1978] & 34 \\
DeMets et al. $[1990]$ & 50 (up to $80 \pm 20$ in places) \\
\hline
\end{tabular}


Table 1b. Sedimentation Rates for the Eastern Mediterranean Subduction Zone

\begin{tabular}{|c|c|c|c|c|}
\hline Leg & Site & Location & $\begin{array}{l}\text { Sedimentation } \\
\text { Rate, } \mathrm{m} \mathrm{Myr}^{-1}\end{array}$ & Comments \\
\hline \multicolumn{5}{|c|}{ Pleistocene } \\
\hline ODP 160 & 964 & Calabrian Ridge/Ionian abyssal plain & 4 & absolute minimum \\
\hline ODP 160 & 969 & MedRidge southern Crete & 20 & average 969 Plio-Quaternary \\
\hline DSDP 42 & 374 & Messina abyssal plain & 154 & average 374 Pleistocene \\
\hline DSDP 13 & 131 & Nile cone & $>300$ & rough estimate! \\
\hline ODP 160 & 973 & toe MedRidge & $23-111$ & higher rates owing to turbidites? \\
\hline \multicolumn{5}{|c|}{ Pliocene } \\
\hline ODP 160 & 969 & MedRidge southern Crete & 20 & average 969 Plio-Quaternary \\
\hline DSDP 42 & 374 & Messina abyssal plain & 74 & upper Pliocene \\
\hline DSDP 42 & 374 & Messina abyssal plain & 13 & lower Pliocene \\
\hline DSDP 13 & 126 & Cleft basin & 39 & Plio-Quaternary \\
\hline \multicolumn{5}{|c|}{ Miocene } \\
\hline Messinian & & & & \\
\hline DSDP 42 & 374 & Messina abyssal plain & $>20$ & estimated (halite) \\
\hline DSDP 42 & $375 / 376$ & Florence Rise & $50-60$ & evaporites \\
\hline $\begin{array}{l}\text { DSDP } 13 \\
\text { Tortonian }\end{array}$ & 126 & Cleft basin & 47 & upper-mid-Miocene \\
\hline $\begin{array}{l}\text { DSDP } 42 \\
\text { Serravallian }\end{array}$ & $375 / 376$ & Florence Rise & 70 & marlstone/turbidites \\
\hline $\begin{array}{l}\text { DSDP } 42 \\
\text { Langian }\end{array}$ & $375 / 376$ & Florence Rise & 17 & marlstone/turbidites \\
\hline $\begin{array}{l}\text { DSDP } 42 \\
\text { Burdigalian }\end{array}$ & $375 / 376$ & Florence Rise & 100 & marl/limestones \\
\hline DSDP 42 & $375 / 376$ & Florence Rise & 17 & marl/limestones \\
\hline Aquitan & - & - & - & - \\
\hline Oligocene $^{\mathrm{a}}$ & & & 41 & \\
\hline Eocene $^{\mathrm{a}}$ & & & 41 & \\
\hline Paleocene $^{\mathrm{a}}$ & & & 41 & \\
\hline
\end{tabular}

${ }^{\mathrm{a}}$ Estimated from seismic profile.

dimension is gained under the assumption that the image of the wedge along each seismic profile is representative for a $1-\mathrm{km}$-wide slice through the forearc.

\subsection{Solid Balance Calculations}

[36] For the balance calculation, only the solid portion of the basin model and accreted wedge along each line is used (right column in Tables 2 and 3). The relative rate of accretion is obtained by dividing the solid area of the wedge through that of the total sediment input. The rate is hence the percentage of the total input which was transferred from the incoming plate to the upper plate forearc. Similarly, the relative amount of subducted material can be obtained as the ratio of subducted material ( area $_{\text {sed. input }}-$ area $\left._{\text {accr. wedge }}\right)$ relative to the total input. As to be expected from the tremendous variation of the accretionary wedge from west to east, the rate of sediment accretion changes from approximately $60 \%$ (line 3 ) and $40 \%$ (line 6 ) in the west to $20 \%$ (line $18 / 19)$ in the main collision zone, before increasing again to approximately $25 \%$ in the east (line 30 ; see Table 4 ). In an earlier balance estimate, the aforementioned mud volcanism in the collision zone has been proposed to represent $5 \%$ of the total bulk volume of accreted wedge [Kopf, 1999]. With respect to this solid rock balance, this would equal only approximately $1 \%$ of the sedimentary input.

[37] Concerning the absolute amount of material being subducted and recycled into the mantle, a systematic increase from west to east is observed. In the west, where the accretionary rate is very high (line 3 ), only $17.7 \mathrm{~km}^{3}$ of solid rock are subducted per kilometer of trench per million years. A stepwise increase in the subducted volume occurs over lines 6 $\left(26 \mathrm{~km}^{3}\right)$ and $18 / 19\left(34.5 \mathrm{~km}^{3}\right)$ to reach $47.5 \mathrm{~km}^{3}$ of solid

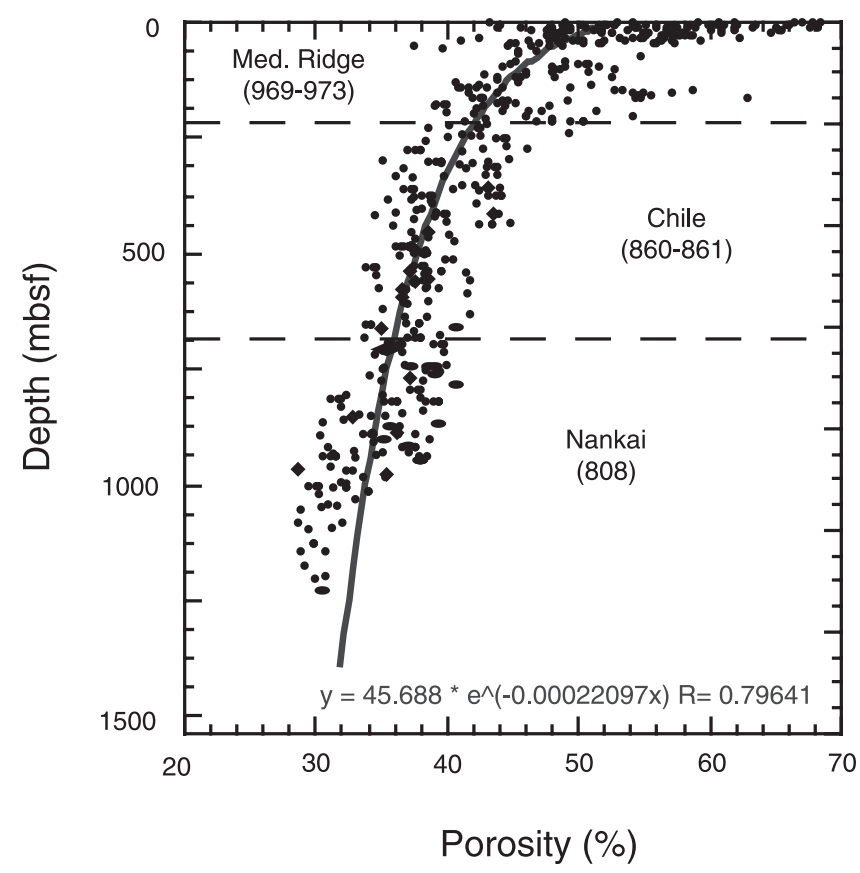

Figure 7. Porosity-depth curve compiled from ODP drilling results from MedRidge, Chile, and Nankai accretionary prisms (see text for references). 

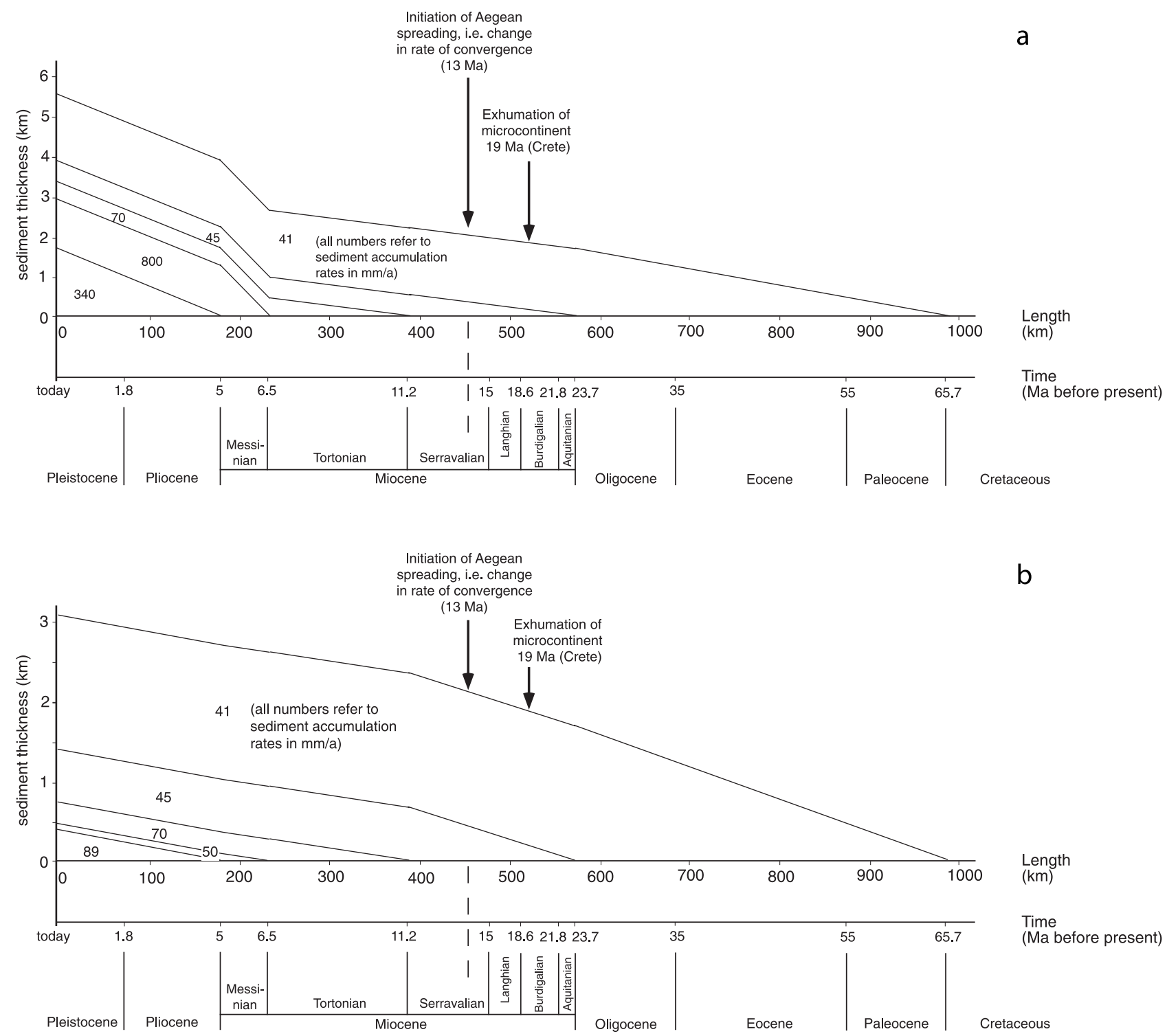

Figure 8. Model for sedimentary basin fill reconstructed from sedimentation rates and plate kinematic data. (a) Model using conservative sedimentation rates, which was balanced against the accretionary prism along lines 3,6, and 18/19. (b) Model using higher sedimentation rates to accommodate for deposition of the Nile deep-sea fan. This latter model is balanced against the prism along line 30 . See Table 1.

rock per kilometer per million years (Table 4). The latter value plots in the upper range of subduction fluxes on a global scale [von Huene and Scholl, 1991].

\section{Discussion}

[38] This discussion is chiefly concerned with two aspects. First, we briefly review the influence of various factors on subduction-accretion dynamics, and hence mass balances. Special attention will be drawn to quantitative aspects like rate of accretion and outward wedge growth and volume flux of subduction along convergent margins on a global scale. We then tie the results from our mass balance study into the regional framework of the Mediterranean, compare it to the Chilean margin, and discuss the possibility of forearc evolution being a self-regulating process.
[39] A cyclic transfer of material between crust (including sedimentary cover) and upper mantle is a necessity for longterm dynamics of plate kinematics, and has been accounted for in a global balance of subduction-accretion systems by von Huene and Scholl [1991, 1993] and Scholl and von Huene [2001]. It has been shown that, since the Oligocene (35 Ma), the volume of deep subducted material (i.e., to mantle depth) equals the best estimates of the juvenile igneous material added to the crust [e.g., Kay, 1980; Howell, 1989]. For accreting convergent margin scenarios, the longterm rate of subducted sediment is $\sim 25-50 \mathrm{~km}^{3} \mathrm{Myr}^{-1}$ per kilometer trench length [von Huene and Scholl, 1991]. This equals $\sim 70 \%$ of the material entering the trench. By contrast, the same authors estimated that along forearcs bordered by large prisms ( $>40 \mathrm{~km}$ width) only $30 \%$ accretes to the overriding plate, while $70 \%$ undergoes subduction. 
Table 2. Porosity Depth Information of Basin Models Calculated From the Exponential Relationship Given in Figure 7 for 1000-m Depth Intervals ${ }^{\mathrm{a}}$

\begin{tabular}{|c|c|c|c|c|c|c|}
\hline \multirow{2}{*}{$\begin{array}{l}\text { Depth, } \\
\text { mbsf }\end{array}$} & \multirow{2}{*}{$\begin{array}{c}\text { Porosity, } \\
\%\end{array}$} & \multirow{2}{*}{$\begin{array}{l}\text { Area, } \\
\mathrm{km}^{2}\end{array}$} & \multicolumn{2}{|c|}{ Fluids } & \multicolumn{2}{|c|}{ Solids } \\
\hline & & & Factor & Area, $\mathrm{km}^{2}$ & Factor & Area, $\mathrm{km}^{2}$ \\
\hline \multicolumn{7}{|c|}{ Basin Model Lines 3, 6, and 18/19 } \\
\hline $0-1000$ & 41.2 & 515.0 & 0.4 & 212.2 & 0.6 & 302.8 \\
\hline $1000-2000$ & 33.4 & 492.5 & 0.3 & 164.5 & 0.7 & 328.0 \\
\hline $2000-3000$ & 26.6 & 258.5 & 0.3 & 68.8 & 0.7 & 189.7 \\
\hline $3000-4000$ & 21.3 & & 0.2 & & 0.8 & \\
\hline $4000-5000$ & 17.1 & & 0.2 & & 0.8 & \\
\hline $5000-6000$ & 13.6 & & 0.1 & & 0.9 & \\
\hline Total area & & 1266.0 & & 445.4 & & 820.6 \\
\hline \multicolumn{7}{|c|}{ Basin Model Line 30} \\
\hline $0-1000$ & 41.2 & 515.0 & 0.4 & 212.2 & 0.6 & 302.8 \\
\hline $1000-2000$ & 33.4 & 515.0 & 0.3 & 172.0 & 0.7 & 343.0 \\
\hline $2000-3000$ & 26.6 & 434.5 & 0.3 & 115.6 & 0.7 & 318.9 \\
\hline $3000-4000$ & 21.3 & 183.0 & 0.2 & 39.0 & 0.8 & 144.0 \\
\hline $4000-5000$ & 17.1 & 76.0 & 0.2 & 13.0 & 0.8 & 63.0 \\
\hline $5000-6000$ & 13.6 & 24.0 & 0.1 & 3.3 & 0.9 & 20.7 \\
\hline Total area & & 1747.5 & & 555.0 & & 1192.5 \\
\hline
\end{tabular}

${ }^{\mathrm{a}}$ Depth intervals are averaged over 20 porosity values calculated per $50-\mathrm{m}$ interval. Data from area estimates of the basin input models of lines 3,6, $18 / 19$ and 30 have been divided into solid and fluid fractions using the porosity results.

On the basis of new geological and geophysical data acquired during the past decade, this latter value has recently been revised to $40 \%$ being subducted [Scholl and von Huene, 2001]. Given the difference in resolution and the along-strike variation of the seismic lines of our study, the mean average of $36 \%$ subduction rate along the four MedRidge profiles agrees well when compared to the estimate of $40 \%$ subduction along margins hosting large accretionary wedges. However, our results also show that both the absolute amount of accreted solid rock mass and the relative rate of subduction and accretion can vary by a factor of three within a few hundred $\mathrm{km}$ along strike of the same margin (see Table 4).

[40] Before we relate the variation in our data to a systematic, possibly self-regulating model of forearc evolution, we want to briefly examine which factors may generally control the relative importance of subduction, accretion, or subduction erosion. Numerous workers have focused on the control of accretion dynamics. A sedimentary cover sufficiently thick and water-saturated to compensate crustal roughness (horst and graben structures, seamounts, etc.) and to lubricate the plate interface plays a crucial role to allow accretion [von Huene and Scholl, 1991; Le Pichon et al., 1993]. In contrast, rough seafloor topography owing to abundant seamounts [e.g., von Huene and Lallemand, 1990; Ranero and von Huene, 2000] or catastrophic events like spreading ridge subduction [Behrmann and Kopf, 2001] are known to disaggregate the forearc, allowing subduction of the material. Apart from these parameters of the upper subduction zone, the basal friction at greater depth, the dip angle of the downgoing plate, and the width of the subduction channel [Cloos and Shreve, 1988a, 1988b], or subduction gate [Kukowski et al., 1994] are crucial. A great deal of analogue and numerical modeling has been carried out on the behavior of Coulomb wedges. Analog experiments and observations in vivo suggest that subduction erosion is favored when basal friction is high [Kukowski et al., 1994; von Huene and
Scholl, 1991]. The lower the slope angle $(\alpha)$ of the wedge, and the higher the angle of dip of the slab $(\beta)$, the more material is subducted. On the other hand, numerical modeling [Willett, 1992], sandbox modeling [Kukowski et al., 1994, 2002], and observations [e.g., Flueh et al., 1998] illustrate that low friction facilitates frontal accretion. More complex modeling including "weak" layers of an inferred lubricant (such as fluid overpressure [Rice, 1992], evaporites [Reston et al., 2002], or clay minerals [Logan and Rauenzahn, 1987]) may cause basal accretion of entrained duplexes and a jumping décollement [Kukowski et al., 2002]. Similar effects are observed without inhomogeneities within the incoming sediment pile, but a relatively wide "subduction gate" when simulating subduction-accretion in a low basal friction scenario [Gutscher et al., 1998]. Outward growth of a wedge is maximized when a deep décollement allows frontal accretion of thick slices of sediment. Vice versa, subduction erosion may cause a landward retreat of the deformation front [von Huene and Scholl, 1991]. The

Table 3. Porosity Depth Information of Accretionary Wedges Calculated From the Exponential Relationship Given in Figure 7 for 1000-m Depth Intervals ${ }^{\mathrm{a}}$

\begin{tabular}{|c|c|c|c|c|c|c|}
\hline \multirow{2}{*}{$\begin{array}{c}\text { Depth, } \\
\text { mbsf }\end{array}$} & \multirow{2}{*}{$\begin{array}{c}\text { Porosity, } \\
\%\end{array}$} & \multirow{2}{*}{$\begin{array}{c}\text { Area, } \\
\mathrm{km}^{2}\end{array}$} & \multicolumn{2}{|c|}{ Fluids } & \multicolumn{2}{|c|}{ Solids } \\
\hline & & & Factor & Area, $\mathrm{km}^{2}$ & Factor & Area, $\mathrm{km}^{2}$ \\
\hline \multicolumn{7}{|c|}{ Wedge Line 3} \\
\hline $0-1000$ & 41.2 & 132.6 & 0.4 & 54.6 & 0.6 & 78.0 \\
\hline $1000-2000$ & 33.4 & 157.5 & 0.3 & 52.6 & 0.7 & 104.9 \\
\hline $2000-3000$ & 26.6 & 135.3 & 0.3 & 36.0 & 0.7 & 99.3 \\
\hline $3000-4000$ & 21.3 & 110.5 & 0.2 & 23.5 & 0.8 & 87.0 \\
\hline $4000-5000$ & 17.1 & 69.4 & 0.2 & 11.9 & 0.8 & 57.5 \\
\hline $5000-6000$ & 13.6 & 45.4 & 0.1 & 6.2 & 0.9 & 39.2 \\
\hline $6000-7000$ & 11 & 14.0 & 0.1 & 1.5 & 0.9 & 12.5 \\
\hline $7000-8000$ & 8.9 & 6.8 & 0.1 & 0.6 & 0.9 & 6.2 \\
\hline Total area & & 671.5 & & 186.3 & & 484.5 \\
\hline \multicolumn{7}{|c|}{ Wedge Line 6} \\
\hline $0-1000$ & 41.2 & 94.7 & 0.4 & 39.0 & 0.6 & 55.7 \\
\hline $1000-2000$ & 33.4 & 113.5 & 0.3 & 37.9 & 0.7 & 75.6 \\
\hline $2000-3000$ & 26.6 & 107.4 & 0.3 & 28.6 & 0.7 & 78.8 \\
\hline $3000-4000$ & 21.3 & 98.6 & 0.2 & 21.0 & 0.8 & 77.6 \\
\hline $4000-5000$ & 17.1 & 43.7 & 0.2 & 7.5 & 0.8 & 36.2 \\
\hline $5000-6000$ & 13.6 & 3.8 & 0.1 & 0.5 & 0.9 & 3.3 \\
\hline Total area & 461.8 & & & 134.5 & & 327.3 \\
\hline \multicolumn{7}{|c|}{ Wedge Line 18/19 } \\
\hline $0-1000$ & 41.2 & 58.8 & 0.4 & 24.2 & 0.6 & 34.6 \\
\hline $1000-2000$ & 33.4 & 66.9 & 0.3 & 22.3 & 0.7 & 44.5 \\
\hline $2000-3000$ & 26.6 & 64.0 & 0.3 & 17.0 & 0.7 & 47.0 \\
\hline $3000-4000$ & 21.3 & 44.2 & 0.2 & 9.4 & 0.8 & 34.8 \\
\hline $4000-5000$ & 17.1 & 5.1 & 0.2 & 0.9 & 0.8 & 4.2 \\
\hline Total area & & 239.0 & & 73.9 & & 165.1 \\
\hline \multicolumn{7}{|c|}{ Wedge Line 30} \\
\hline $0-1000$ & 41.2 & 79.8 & 0.4 & 32.9 & 0.6 & 46.9 \\
\hline $1000-2000$ & 33.4 & 98.1 & 0.3 & 32.8 & 0.7 & 65.3 \\
\hline $2000-3000$ & 26.6 & 87.2 & 0.3 & 23.2 & 0.7 & 64.0 \\
\hline $3000-4000$ & 21.3 & 66.5 & 0.2 & 14.2 & 0.8 & 52.4 \\
\hline $4000-5000$ & 17.1 & 46.5 & 0.2 & 7.9 & 0.8 & 38.5 \\
\hline $5000-6000$ & 13.6 & 15.8 & 0.1 & 2.1 & 0.9 & 13.6 \\
\hline $6000-7000$ & 11 & 6.3 & 0.1 & 0.7 & 0.9 & 5.6 \\
\hline $7000-8000$ & 8.9 & 2.3 & 0.1 & 0.2 & 0.9 & 2.1 \\
\hline Total area & 402.5 & & & 114.0 & & 288.5 \\
\hline
\end{tabular}

${ }^{\mathrm{a}}$ Depth intervals are averaged over 20 porosity values calculated per $50-\mathrm{m}$ intervals. Data from area estimates of the accreted wedge of lines 3, 6, 18/19, and 30 have been divided into solid and fluid fractions using the porosity results. 
Table 4. Results From Balance Estimates of Sediment Basin Input Versus Accreted Material, Both as Absolute Values and as Relative Percentages ${ }^{\mathrm{a}}$

\begin{tabular}{|c|c|c|c|c|c|c|c|c|}
\hline & \multicolumn{3}{|c|}{ Area, $\mathrm{km}^{2}$} & \multicolumn{2}{|c|}{$\begin{array}{l}\text { Solid Volume, } \mathrm{km}^{3} \text { per } \\
\mathrm{km} \text { trench and Myr }\end{array}$} & \multicolumn{2}{|c|}{ Rate, $\%$} & \multirow{2}{*}{$\begin{array}{l}\text { Volume Flux } \\
\text { of Subducted } \\
\text { Solid Portion, } \\
\mathrm{km}^{3} \text { per km } \\
\text { trench and Myr }\end{array}$} \\
\hline & Total & Fluids & Solids & Subducted & Accreted & Accretionary & Subduction & \\
\hline $\begin{array}{l}\text { Basin input } \\
\text { Wedge }\end{array}$ & $\begin{array}{l}1266 \\
671\end{array}$ & $\begin{array}{l}445.4 \\
186.3\end{array}$ & $\begin{array}{l}820.6 \\
484.5\end{array}$ & 484.5 & 336.0 & 59.1 & 41.0 & 18 \\
\hline $\begin{array}{l}\text { Basin input } \\
\text { Wedge }\end{array}$ & $\begin{array}{l}1266 \\
462\end{array}$ & $\begin{array}{l}445.4 \\
134.5\end{array}$ & $\begin{array}{l}820.6 \\
327.3\end{array}$ & 493.3 & 327.3 & 39.9 & 60.1 & 26 \\
\hline $\begin{array}{l}\text { Basin input } \\
\text { Wedge }\end{array}$ & $\begin{array}{l}1266 \\
239\end{array}$ & $\begin{array}{l}445.4 \\
73.9\end{array}$ & $\begin{array}{l}820.6 \\
165.1\end{array}$ & 655.5 & 165.1 & 20.1 & 79.9 & 35 \\
\hline $\begin{array}{l}\text { Basin input } \\
\text { Wedge }\end{array}$ & $\begin{array}{l}1748 \\
402\end{array}$ & $\begin{array}{l}555.0 \\
114.0\end{array}$ & $\begin{array}{l}1192.5 \\
288.5\end{array}$ & 904.0 & 288.5 & 24.2 & 75.8 & 48 \\
\hline
\end{tabular}

\footnotetext{
${ }^{\mathrm{a}}$ Absolute values are given in $\mathrm{km}^{3}$ solid rock per $\mathrm{km}^{2}$ and $\mathrm{km}$ trench length. Note that the apparent W-E decrease in rate of
} accretion is partly an effect of the elevated sediment accumulation of the Nile river. See text for discussion.

stronger a catastrophic event has affected the forearc by removal of rock volume into the deep subduction zone, the more likely a self-regulating period of rapid forearc growth will follow [Behrmann and Kopf, 2001].

[41] If applied to the Mediterranean Ridge, the majority of the parameters controlling subduction-accretion are suggestive of frontal addition being the main forearc-building process during the last $\sim 20$ Myr. Given further that the angle of $\operatorname{dip}(\beta)$ of the downgoing slab is relatively shallow (J. Makris, personal communication, 2000), this also favors frontal accretion [Willett, 1992]. Thick sedimentary sequences are found on the Ionian, Sirte, and Herodotus abyssal plains (Figure 1). The extreme width of the accretionary wedge, especially with respect to its thickness, has been attributed to lowered basal friction due to fluid overpressure [Le Pichon et al., 1982]. This finding is supported by the landward vergence of the protothrust zone along line 3 (Figure 2), which has previously been suggested to result in rapidly deposited trench sequences (e.g., along the Cascadia margin [MacKay et al., 1992]). A second argument for rapid accumulation and imbrication is, at least in the frontal part of the wedge, the Messinian evaporite deposits [Chaumillon and Mascle, 1997; Reston et al., 2002]. These layers, together with clay-rich terrigenous deposits (e.g., from the Nile cone), are characterized by low friction coefficients and hence act as lubricants. By contrast, only occasional seafloor topographic highs (like the Bannock Seamount [von Huene et al., 1997]) hamper continuous off scraping of the several kilometers thick incoming succession. The situation changes drastically when going to the area where all seafloor has been consumed between Libya and Crete (lines 6 and 18/19). Here, the growth of the wedge is hindered, and as a result of being clamped between the two continental margins, the wedge behaves similar to an uplifted plug and retrowedge (see Beaumont et al. [1999, Figures 1 and 2] or Ellis et al. [1999]). In addition, pore pressure effects play a minor role in facilitating plate convergent movement, because the Libyan Margin consists of well-consolidated sedimentary rocks compared to undercompacted trench sediments farther east (line 30, Herodotus abyssal plain) or west (line 3, Sirte abyssal plain, Figure 1).

[42] The effect of incipient narrowing of the basin on the dynamics of subduction, accretion, and outward migration of the deformation front is illustrated in Figures 9a-9c. A systematic increase in the amount of subducted sediment is observed from west to east (Figure 9a). While values of about $18-35 \mathrm{~km}^{3}$ of solid rock per kilometer of trench length per million years bracket the average $30 \mathrm{~km}^{3} \mathrm{~km}^{-1} \mathrm{Myr}^{-1}$ estimated for subduction transfer into the mantle [von Huene and Scholl, 1991]. In contrast, the easternmost subduction flux of almost $50 \mathrm{~km}^{3} \mathrm{~km}^{-1} \mathrm{Myr}^{-1}$ (line 30) range at the upper limit of material transfer on a global scale. Similarly high transfer rates are seen along the Chile margin, where collision of the active spreading ridge has caused forearc disaggregation and subduction erosion at estimated rates of up to 59-64 $\mathrm{km}^{3} \mathrm{~km}^{-1} \mathrm{Myr}^{-1}$ [Behrmann and Kopf, 2001] (see below).

[43] When comparing the rate of accretion along the four seismic lines (Figure 9b), the minimum solid rock volume subducted corresponds to the maximum accretion (Figure 9a, line 3). The rate of accretion decreases toward the collision from both the western and eastern direction, with a minimum of $20 \%$ accreted rock mass along zone line 18/19. As an effect of larger amounts of sedimentary input along line 30 across parts of the Nile deep-sea fan, the percentage of accreted material is higher than at line 18/19 (Figure 9b), despite the large volumes of rock subducted to mantle depth (Figure 9a). A matching trend is seen between rate of accretion and rate of outward growth of the wedge with time (Figure 9c). In the area where the Cyrenaica Promontory collides with the toe of the prism (line 18/19), outward migration is less than $8 \mathrm{~km} \mathrm{Myr}^{-1}$, and has supposedly 
A

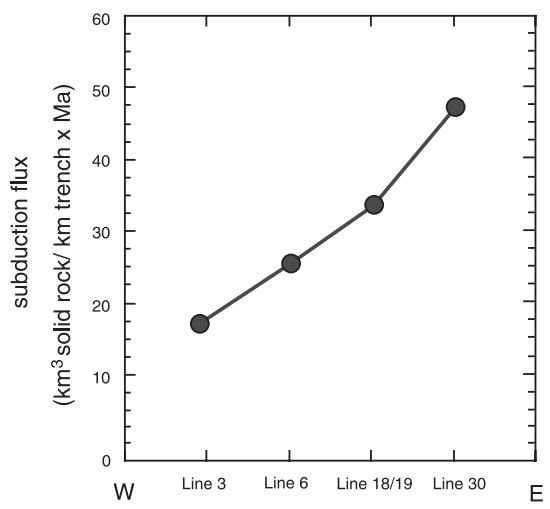

B

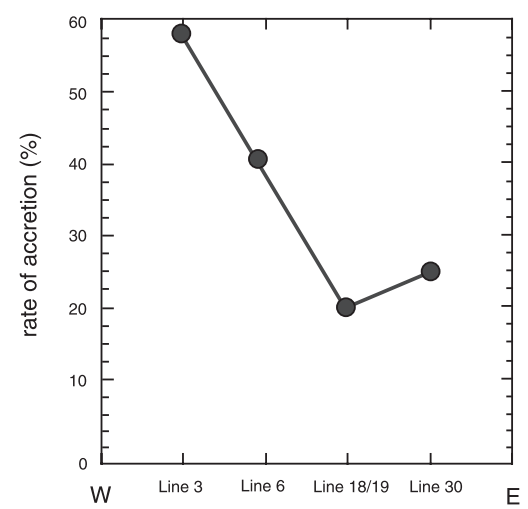

C

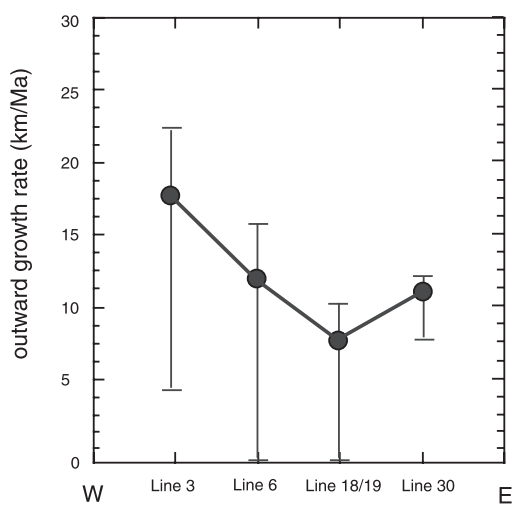

Figure 9. Sketch illustrating the volume flux (in cubic kilometer of subducted solid rock volume per kilometer of trench per million years). (a) Variable rate of accretion (in \% of available basin input) and rate (b) of outward growth along strike (in $\mathrm{km} \mathrm{Myr}^{-1}$ ) and (c) of the Mediterranean Ridge accretionary prism. Note that the variation along each line is not an error bar, but a range of the outward growth rate with time. The minima reflect post-Messinian, while the maxima represent pre-Messinian rates. See text.

come to a stillstand recently due to complete consumption of abyssal plain sediments. This agrees with the proposed decrease in growth rate since the Messinian [Kastens, 1991]. In addition to the narrowing of the basin, another main reasons for the decrease (lines 3 and 30), or stillstand (lines 6 and 18/19) in outward growth is the deposition of salt during the latest Miocene. These evaporites act as a lubricant, so that underthrusting and internal imbrication of thrust slices rather than outward growth due frontal addition of large sediment packages takes place [Kukowski et al., 2002; Reston et al., 2002]. Even in the west where the wedge is not clamped between Africa and Eurasia, the outward migration slows down to $4.4 \mathrm{~km} \mathrm{Myr}^{-1}$ after salt deposition (see lower marker for line 3 in Figure 9c). However, the overall accretion along this line has led to growth rates of $17.7 \mathrm{~km} \mathrm{Myr}^{-1}$ since the early Miocene (with temporary maxima as high as $22.5 \mathrm{~km} \mathrm{Myr}^{-1}$, Figure 9c). These results suggest that the subduction gate must have been "closed" since exhumation took place some 19 Myr ago.

[44] Among the convergent plate margins which have been investigated by geophysical techniques and drilling, average outward growth rates exceeding $15 \mathrm{~km} \mathrm{Myr}^{-1}$ have not been reported. Even for accretionary wedges of similar size as the Mediterranean Ridge, like Makran or Alaska, no evidence is provided that these systems grow excessively fast. By contrast, recent ODP drilling in the Nankai accretionary prisms off SW Japan suggests that large out-ofsequence thrust allowed the wedge to grow $\sim 40 \mathrm{~km}$ within the past 2 Myr [Moore et al., 2001]. This value is similar to the average growth along line 3 across the MedRidge, but may reflect an anomalous phase in case of Nankai. If the overall width of accreted strata of SW Japan is traced to the onshore outcrops of the Tertiary Shimanto Belt accretionary complex on Shikoku island, a total width of $\sim 170 \mathrm{~km}$ (from the deformation front to the onshore suture between the Tertiary and Cretaceous part of the Shimanto Belt) corresponds to $65 \mathrm{Ma}$ period of subduction-accretion. The average outward growth at Nankai is hence less than $3 \mathrm{~km} \mathrm{Myr}^{-1}$ (which admittedly does not account for the complex tectonic framework and collisional history in the area [Underwood et al., 1993], which makes Nankai one of the slowly growing margins on Earth [see also Kastens, 1991]. Similarly, Barnard [1978] suggested some 30-50 km for the Quaternary (i.e., 2 Ma) outward growth of the Cascadia wedge off Washington. Like for Nankai, such a rate is not representative for long-term accretionary behavior, but clearly influenced by postglacial sedimentation dynamics.

[45] If we finally tie our balance results into global as well as local studies, we see some similarities in either case despite the different resolution of the approaches. As mentioned above, the estimated $40 \%$ of subduction along margins with large prisms [Scholl and von Huene, 2001] are very similar to our mean average value of $36 \%$ along the 4 lines across the MedRidge. This finding suggests that the global approach is valid, which necessarily could not account for regional variations on a $10-\mathrm{km}$ scale.

[46] Apart from the global estimates, very few local mass balance estimates exist. The majority of them are concerned with chemical fluxes (often including the volcanic arc [e.g., Plank and Langmuir, 1998]), and hence do not require a detailed knowledge of the ratio of accreted versus subducted sediment. Other balance studies cover entire orogenic events, but often lack resolution [Ricken et al., 2000]. The only comparable study across an active convergent margin at a similar resolution examined the impact of a spreading centre into the Chilean forearc. Despite the obvious regional differences between the Mediterranean and southern Chile, striking similarities can be seen in subduction-accretion dynamics from these high-resolution balance studies [Behrmann and Kopf, 2001; this work]. The onset of rapid off scraping and build up of an accretionary wedge after a catastrophic event (in Chile subduction of an active, buoyant (and hence topographically elevated) spreading ridge; in the Mediterranean the slab break off and rise of the microcontinental remnants) range in the same order of magnitude. In areas of postcollisional accretion, low-subduction fluxes (Chile $22 \mathrm{~km}^{3} \mathrm{~km}^{-1} \mathrm{Myr}^{-1}$; MedRidge $17.7 \mathrm{~km}^{3} \mathrm{~km}^{-1} \mathrm{Myr}^{-1}$ ) and high rates of accretion (Chile 62\%; MedRidge 59\%) are found. In contrast, areas of major collision show low rates of accretion 
(Chile 12\%; MedRidge 20\%) and corresponding high material flux into the deep subduction zone. The range of material discharge $\sim 35-46 \mathrm{~km}^{3} \mathrm{~km}^{-1} \mathrm{Myr}^{-1}$ in the collision zone south of Crete (lines 18/19 and 30) suggest that the leading edge of the African Shelf may protrude far to the north at some subsurface depth which cannot be resolved on our MCS data. This frontal part of the continental plate forces deep accreted rock into a position beneath the backstop and, subsequently, into the mantle. West of the collision zone, the picture changes drastically. As there are no major unconformities imaged on the seismic profiles, we propose that constant growth of an accretionary wedge may occur over a duration of $20 \mathrm{Myr}$ (and more, if circumstances allow it). If they do not, like in the central part in the MedRidge collision zone, the rate of accretion (see minimum in Figure 9b) and outward growth is slowed down $\left(7.6 \mathrm{~km} \mathrm{Myr}^{-1}\right.$ on average, but basically zero for the previous 4-5 Myr after consumption of the abyssal plain seafloor along line 18/19, Figure 9c) with respect to the undisturbed accumulation and growth farther west (line 3). Miocene rates of $>20 \mathrm{~km} \mathrm{Myr}^{-1}$, as estimated from the pre-Messinian wedge on the seismic profiles across the MedRidge, represent extreme maxima on a global scale (growth rates of $2-10 \mathrm{~km} \mathrm{Myr}^{-1}$ for Peru, Nankai, Barbados, and Makran, given in order of increase [Kastens, 1991]). Hence our results support the hypothesis that highly destructive collisional events in the forearc, like the slab break off and exhumation of thrust sheets, can be followed by periods of accretion and continuous growth of accretionary wedges.

\section{Conclusions}

[47] 1. The high-resolution mass balance of accreted versus subducted material in the continental collision zone of the eastern Mediterranean shows strong variations along strike. The percentage of accreted material relative to the sediment supplied ranges from $60 \%$ in the west to only $20 \%$ in the main collision zone.

[48] 2. The rate of accretion is mirrored by enormous average outward growth rates of the Mediterranean Ridge up to $17.7 \mathrm{~km} \mathrm{Myr}^{-1}$, which makes it the fastest growing wedge known on Earth. Outward growth corresponds nicely with the incorporation of weak clay- and evaporite-bearing layers and the overall low angle of dip of the downgoing slab.

[49] 3. The solid rock mass removed by subduction and subduction erosion is up to $47.6 \mathrm{~km}^{3} \mathrm{~km}^{-1} \mathrm{Myr}^{-1}$ ranges at the upper end of global estimates by von Huene and Scholl [1991]. Material transfer into the deep subduction zone is particularly high where the wedge is clamped between Libya and Crete, and where the thickness of the incoming sediment is large.

[50] 4. The rapid buildup and outward migration of the wedge has been triggered by the slab break off and exhumation of Crete at $\sim 19 \mathrm{Ma}$. Such catastrophic events may be a trigger for a self-regulating forearc dynamics of subduction zones, as has been suggested previously for the southern Chile accretionary prism [Behrmann and Kopf, 2001].

[51] Acknowledgments. The authors thank Anna Volkonskaia and Alain Moreau for assistance in data retrieval and preprocessing and Bernhard Stöckhert and Hans-Peter Harjes for helpful discussion and having provided preprints of their work. Financial and technical support for this research from IFREMER, GENAVIR, and CNRS-INSU for surveys with R/V Nadir and R/V L'Atalante (to J.M.), BASF AG, Germany (to A.K.), and the EU large-scale facility at GEOMAR, Kiel, Germany (to J.M. and A.K.) is gratefully acknowledged. The manuscript benefited from the detailed criticism and helpful suggestions by Andy Fisher and Nina Kukowski. Achim Kopf dedicates this paper to Roland von Huene for his outstanding achievements and our enthusiastic discussions concerning the identification and quantification of mass transfer processes at convergent margins.

\section{References}

Altherr, R., H. Kreuzer, I. Wendt, H. Lenz, G. A. Wagner, J. Keller, W. Harre, and A. Hondorf, A late Oligocene/early Miocene high-temperature belt in the Attico-Cycladic crystalline complex (SE Pelagonian, Greece), Geol. Jahrb., Reihe E, 23, 97-164, 1982.

Argus, D. F., Current plate motions and crustal deformation, Ph.D. thesis, 175 pp., Northwestern Univ., Evanston, Ill., 1990.

Armijo, R., H. Lyon-Caen, and D. Papanastassiou, East-west extension and Holocene normal-fault scarps in the Hellenic arc, Geology, 20, 491-494, 1992.

Athy, L. F., Density, porosity, and compaction of sedimentary rocks, $A A P G$ Bull., 14, 1-23, 1930.

Avedik, F., V. Renard, J. P. Allenou, and B. Morvan, Single bubble air gun array for deep exploration, Geophysics, 58, 366-382, 1993.

Barnard, W. D., The Washington continental slope: Quaternary tectonics and sedimentation, Mar. Geol., 27, 79-114, 1978.

Bassias, Y., and C. Triboulet, Apports de l'analyse minéralogique et pétrologique à la connaissance de l'origine et de l'histoire mètamorphique des phyllades du Parnon (Péloponnèse, Grèce), Rev. Géol. Dyn. Géogr. Phys., 26, 215-228, 1985 .

Beaumont, C., S. Ellis, and O. A. Pfiffner, Dynamics of sediment subduction-accretion at convergent margins: Short-term modes, long-term deformation, and tectonic implications, J. Geophys. Res., 104, 17,57317,601, 1999.

Behrmann, J. H., and A. Kopf, Balance of tectonically accreted and subducted sediment at the Chile Triple Junction (Ocean Drilling Program Leg 141), Int. J. Earth Sci., 90, 753-768, 2001.

Behrmann, J. H., S. D. Lewis, R. J. Musgrave, and Shipboard Scientific Party Leg 141, Proceedings of the Ocean Drilling Program, Initial Reports, vol. 141, 709 pp., Ocean Drilling Program, College Station, Tex., 1992.

Ben-Avraham, Z., G. Tibor, A. F. Limonov, M. B. Leybov, M. K. Ivanov, M. Y. Tokarev, and J. M. Woodside, Structure and tectonics of the eastern Cyprian Arc, Mar. Pet. Geol., 12, 263-271, 1995.

Bonneau, M., Correlation of the Hellenide nappes in the southeast Aegean and their tectonic reconstruction, in Geological Evolution of the Eastern Mediterranean, edited by J. E. Dixon and A. H. F. Robertson, Spec. Publ. Geol. Soc. London, 17, 517-527, 1984.

Camerlenghi, A., M. B. Cita, B. Della Vedova, N. Fusi, L. Mirabile, and G. Pellis, Geophysical evidence of mud diapirism on the Mediterranean Ridge accretionary complex, Mar. Geophys. Res., 17, 115-141, 1995.

Chase, C. G., Plate kinematics: The Americas, East Africa, and the rest of the world, Earth Planet. Sci. Lett., 37, 355-368, 1978.

Chaumillon, E., Structure de la Ride Méditerranéenne: Apports de la sismisue réflexion multitrace. La Ride Méditerranéenne: Un prisme d'accretion atypique, Ph.D. thesis, 225 pp., Univ. Paris VI, Paris, 1995.

Chaumillon, E., and J. Mascle, From foreland to forearc domains: new multichannel seismic reflection survey of the Mediterranean Ridge accretionary complex (eastern Mediterranean), Mar. Geol., 138, 237-259, 1997.

Chaumillon, E., J. Mascle, and H. J. Hofmann, Deformation of the western Mediterranean Ridge: Importance of Messinian evaporitic formations, Tectonophysics, 263, 162-190, 1996.

Cloos, M., and R. L. Shreve, Subduction-channel model of prism accretion, melange formation, sediment subduction, and subduction erosion at convergent plate margins, 1. Background and description, Pure Appl. Geophys., 128, 456-500, 1988a.

Cloos, M., and R. L. Shreve, Subduction-channel model of prism accretion, melange formation, sediment subduction, and subduction erosion at convergent plate margins, 2. Implications and discussion, Pure Appl. Geophys., 128, 501-505, 1988b.

Davies, J. H., and F. V. von Blanckenburg, Slab breakoff: A model of lithosphere detachment and its test in the magmatism and deformation of collisional orogens, Earth Planet. Sci. Lett., 129, 85-102, 1995.

DeMets, R. G., D. Gordon, F. Argus, and S. Stein, Current plate motions, Geophys. J. Int., 101, 425-478, 1990.

Dercourt, J., et al., Geological evolution of the Tethys Belt from the Atlantic to the Pamirs since the Lias, Tectonophysics, 123, 241-315, 1986. 
Dewey, J. W., W. C. Pitman III, W. B. F. Ryan, and J. Bonin, Plate tectonics and the evolution of the Alpine system, Geol. Soc. Am. Bull., 84, $3137-$ 3180,1973

Ellis, S., C. Beaumont, and O. A. Pfiffner, Geodynamic models of crustalscale episodic tectonic accretion and underplating in subduction zones, J. Geophys. Res., 104, 15,169-15,190, 1999

Emeis, K.-C., A. H. F. Robertson, C. Richter, and Shipboard Scientific Party ODP Leg 160, Proceedings of the Ocean Drilling Program, Initial Reports, vol. 160, 972 pp., Ocean Drill. Program, College Station, Tex., 1996.

Fassoulas, C., A. Kilias, and S. D. Mountraki, Postnappe stacking extension and exhumation of high-pressure/low-temperature rocks in the island of Crete, Greece, Tectonics, 13, 127-138, 1994

Finetti, I., D. Papanikolaou, A. Del Ben, and P. Karvelis, Preliminary geotectonic interpretation of the East Mediterranean Chain and the Hellenic Arc, Bull. Geol. Soc. Greece, 25, 509-526, 1991.

Flueh, E. R., et al., New seismic images of the Cascadia subduction zone from cruise SO108-ORWELL, Tectonophysics, 293, 69-84, 1998.

Fytikas, M., F. Innocenti, P. Manetti, R. Mazzuoli, A. Peccerillo, and L. Villari, Tertiary to Quaternary evolution of volcanism in the Aegean region, in The Geological Evolution of the Eastern Mediterranean, edited by J. E. Dixon and A. H. F. Robertson, Spec. Publ. Geol. Soc. London, 17, 687-700, 1984

Gutscher, M.-A., N. Kukowski, J. Malavieille, and S. E. Lallemand, Material transfer in accretionary wedges from analysis of a systematic series of analog experiments, J. Struct. Geol., 20(4), 407-416, 1998.

Harjes, H.-P., M. Janik, T. Büsselberg, M. Knapmayer, H. Schmidt, J. Schweitzer, and A. Vafidis, Structure and dynamics of the Hellenic subduction zone under Crete from seismic array measurements, paper presented at IASPEI 97, Int. Assoc. of Seismol. and Phys. of the Earth's Inter., Thessaloniki, Greece, 1997.

Howell, D. G., How the growth and freeboard of continents may relate to geometric parameters of mid-ocean spreading ridges, Tectonophysics, $161,343-349,1989$

Hsü, K. J., and D. Bernoulli, Genesis of the Tethys and the Mediterranean, Initial Rep. Deep Sea Drill. Proj., Part I, 943-950, 1978.

Hsü, K. J., et al., Initial Reports of the Deep Sea Drilling Project, vol. 42, U.S. Govt. Print. Off., Washington, D. C., 1978.

Hubral, P., Time migration: Some ray theoretical aspects, Geophys. Prospect., 25, 738-745, 1977 .

Huguen, C., Volcanisme boueux et déformation récente à actuelle au sein de la Ride Méditerranéenne, d'après les données de la campagne PRISMED II, DEA thesis, Univ. Pierre et Marie Curie, Paris, 37 pp., 1998.

IMERSE Working Group, Mediterranean Ridge structure: Results from International Mediterranean Ridge Seismic Experiment (IMERSE), Eos Trans. $A G U, 78,155,1997$.

Jolivet, L., B. Goffé, P. Monié, C. Truffert-Luxey, M. Patriat, and M. Bonneau, Miocene detachment in Crete and exhumation of P-T-t paths of high-pressure metamorphic rocks, Tectonics, 15, 1129-1153, 1996.

Jongsma, D., The geometry and rates of microplate motions in the eastern Mediterranean Sea-Quantitative constraints by using anoxic basins as piercing points, Mar. Geol., 75, 1-29, 1987.

Jongsma, D., J. M. Woodside, P. J. C. King, and J. E. van Hinte, The Medina Wrench: a key to the kinematics of the central and eastern Mediterranean over the past $5 \mathrm{Ma}$, Earth Planet. Sci. Lett., 82, 87-106, 1987.

Kastens, K. A., Rate of outward growth of the Mediterranean Ridge accretionary complex, Tectonophysics, 199, 25-50, 1991

Kay, R. W., Volcanic arc magmas: Implications of a melting-mixing for element recycling in the crust-upper mantle system, J. Geol., 88, 497$522,1980$.

Kopf, A., Fate of sediment during plate convergence at the Mediterranean Ridge accretionary complex: volume balance of mud extrusion versus subduction-accretion, Geology, 27, 87-90, 1999.

Kopf, A., D. Klaeschen, and J. Mascle, Extreme efficiency of mud volcanism in dewatering accretionary prisms, Earth Planet. Sci. Lett., 189 , $295-313,2001$

Kukowski, N., R. von Huene, J. Malavieille, and S. E. Lallemand, Sediment accretion against a buttress beneath the Peruvian continental margin at $12^{\circ} \mathrm{S}$ as simulated with sandbox modeling, Geol. Rundsch., 83(4), $822-$ $831,1994$.

Kukowski, N., S. E. Lallemand, J. Malavieille, M.-A. Gutscher, and T. J. Reston, Mechanical decoupling in sandbox simulation applied to the Mediterranean Ridge, Mar. Geol., 186, 29-42, 2002

Lallemant, S., C. Truffert, L. Jolivet, P. Henry, N. Chamot-Rooke, and B. De Voogd, Spatial transition from compression to extension in the western Mediterranean ridge accretionary complex, Tectonophysics, 234, 33-52, 1994

Le Pichon, X., and J. Angelier, The Hellenic Arc and trench system: A key to the neotectonic evolution of the eastern Mediterranean area, Tectonophysics, 60, 1-42, 1979.
Le Pichon, X., N. Lyberis, J. Angelier, and V. Renard, Strain distribution over the East Mediterranean Ridge: A synthesis incorporating new SeaBeam data, Tectonophysics, 86, 243-274, 1982.

Le Pichon, X., P. Henry, and S. Lallement, Accretion and erosion in subduction zones: The role of fluids, Annu. Rev. Earth Planet. Sci., 21, $307-$ 331,1993

Le Pichon, X., N. Chamot-Rooke, S. Lallement, R. Noomen, and G. Veis, Geodetic determination of the kinematics of central Greece with respect to Europe: Implications for eastern Mediterranean tectonics, J. Geophys. Res., 100, 12,675-12,690, 1995

Ligdas, C. N., I. G. Main, and R. D. Adams, Three-dimensional structure and constraints on the nature of the coupled subduction-spreading process in the Aegean area, Tectonophysics, 201, 199-207, 1992.

Logan, J. L., and K. A. Rauenzahn, Frictional dependence on gouge mixtures of quartz and montmorillonite on velocity, composition and fabric, Tectonophysics, 144, 87-108, 1987.

MacKay, M. E., G. F. Moore, G. R. Cochrane, J. C. Moore, and L. D. Kulm, Landward vergence and oblique structural trends in the Oregon margin accretionary prism: Implications and effect on fluid flow, Earth Planet. Sci. Lett., 109, 477-491, 1992.

MacKay, S., and R. Abma, Imaging and velocity estimation with depthfocusing analysis, Geophysics, 57(12), 1608-1622, 1992.

MacKenzie, D. P., Active tectonics of the Alpine-Himalayan belt: The Aegean Sea and surrounding regions, Geophys. J. R. Astron. Soc., 55, 217-254, 1978

Makris, J., and C. Stobbe, Physical properties and state of the crust and upper mantle of the eastern Mediterranean Sea deduced from geophysical data, Mar Geol, 55, 347-363, 1984

Makris, J., J. Wang, S. D. Odintsov, and G. B. Udintsev, The magnetic field of the eastern Mediterranean Sea, in Geological Structure of the NorthEastern Mediterranean, edited by V. A. Krasheninnikov and J. K. Hall, pp. 75-86, Hist. Prod.-Hall, Jerusalem, Israel, 1994

Mascle, J., et al., Images may show start of European-African Plate collision, Eos Trans. $A G U, 80(37), 421,425,428,1999$.

Maync, W., Lower Cretaceous limestones from The Hellenic Trough, Ionian Basin, Initial Rep. Deep Sea Drill. Proj., 13, 1112-1135, 1973.

Meulenkamp, J. E., M. J. R. Wortel, W. A. Van Wamel, W. Spakman, and E. Strating Hoogerduyn, On the Hellenic subduction zone and the geodynamic evolution of Crete since the late middle Miocene, Tectonophysics, 146, 203-215, 1988 .

Minster, J. B., and T. H. Jordan, Present-day plate motions, J. Geophys. Res., 83, 5331-5354, 1978.

Montadert, L., J. Letouzey, and A. Mauffret, Messinian event: Seismic evidence, Initial Rep. Deep Sea Drill. Proj., 42, Part I, 1037-1050, 1978 .

Moon, C. F., and C. W. Hurst, Fabrics of muds and shales: An overview, Spec. Publ. Geol. Soc. London, 15, 579-593, 1984.

Moore, G. F., et al., Proceedings of the Ocean Drilling Program, Initial Reports, vol. 190, 87 pp. and 2 CD-ROMs, Ocean Drill. Program, College Station, Tex., 2001

Plank, T. A., and C. H. Langmuir, Tracing trace elements from sediment input to volcanic output at subduction zones, Nature, 362, 739-742, 1998.

Ranero, C. R., and R. von Huene, Subduction erosion along the Middle America convergent margin, Nature, 404, 748-752, 2000.

Rea, D. K., and L. J. Ruff, Composition and mass flux of sediment entering the world's subduction zones: Implications for global sediment budgets, great earthquakes, and volcanism, Earth Planet. Sci. Lett., 140, 1-12, 1996.

Reston, T. J., T. Fruehn, R. von Huene, and IMERSE Working Group, The structure and evolution of the western Mediterranean Ridge, Mar. Geol., $186,83-110,2002$

Rice, J. R., Faulty stress states, pore pressure distributions, and the weakness of the San Andreas fault, in Earthquake Mechanics and Transport Properties of Rocks, edited by B. Evans and T. F. Wong, pp. 475-503, Academic, San Diego, Calif., 1992.

Ricken, W., S. Schrader, O. Oncken, and A. Plesch, Turbidite basin and mass dynamics related to orogenic wedge growth: The Rheno-Hercynian case, Geol. Soc. Spec. Publ., 179, 257-280, 2000

Robertson, A. H. F., and A. Kopf, Tectonic setting and processes of mud volcanism on the Mediterranean Ridge accretionary complex: Evidence from Leg 160, Proc. Ocean Deep Program Sci. Results, 160, 665-680, 1998.

Robertson, A. H. F., and Shipboard Scientific Party ODP Leg 160, Mud volcanism on the Mediterranean Ridge: Initial results of Ocean Drilling Program, Leg 160, Geology, 24(3), 239-242, 1996.

Ryan, W. B. F., et al., Hellenic trench sites 127 and 128, Initial Results Deep Sea Drill. Proj., 13, Part 2, 243-322, 1973.

Scholl, D. W., and R. von Huene, Mass flux of continental material at Cenozoic subduction zones-New global and trench-sector calculations 
using new geological and geophysical observations, Eos Trans. $A G U$, 82(47), Fall Meet. Suppl., Abstract V11B-01, 2001.

Seidel, E., H. Kreuzer, and W. Harre, A late Oligocene/early Miocene high pressure belt in the external Hellenides, Geol. Jahrb., Reihe E, 23, 165206, 1982.

Spakman, W., Subduction beneath Eurasia in connection with the Mesozoic Tethys, Geol. Mijnbouw, 65, 145-153, 1986.

Spakman, W., M. J. R. Wortel, and N. J. Vlaar, The Hellenic subduction zone: A tomographic image and its geodynamic implications, Geophys. Res. Lett., 15(1), 60-63, 1988.

Taira, A., I. Hill, J. V. Firth, and Shipboard Scientific Party Leg 131, Proceedings of the Ocean Drilling Program, Initial Reports, vol. 131, 434 pp., Ocean Drill. Program, College Station, Tex., 1991.

Theye, T., and E. Seidel, Uplift-related retrogression history of aragonite marbles in western Crete, Contrib. Mineral. Petrol., 114, 349-356, 1993.

Thomson, S. N., B. Stöckhert, and M. R. Brix, Thermochronology of the high-pressure metamorphic rocks of Crete, Greece: Implications for the speed of tectonic processes, Geology, 26, 259-262, 1998.

Thomson, S. N., B. Stöckhert, and M. R. Brix, Miocene high-pressure metamorphic rocks of Crete, Greece: Rapid exhumation by buoyant escape, in Exhumation Processes: Normal Faulting, Ductile Flow and Erosion, edited by U. Ring et al., Geol. Soc. Spec. Publ., 154, 298-316, 1999.

Truffert, C., N. Chamot-Rooke, S. Lallement, B. De Voogd, P. Huchon, and $X$. Le Pichon, The crust of the western Mediterranean ridge from deep seismic data and gravity modeling, Geophys. J. Int., 114, 360-372, 1993. Underwood, M. B., T. Byrne, J. P. Hibbard, L. DiTullio, and M. M. Laughland, The effects of ridge subduction on the thermal structure of accretionary prisms: A Teriary example from the Shimanto Belt of Japan, in Thermal Evolution of the Tertiary Shimanto Belt, SW Japan: An Example of Ridge-Trench Interaction, edited by M. B. Underwood, Spec. Pap. Geol. Soc. Am., 273, 151-168, 1993.

von Huene, R., and S. Lallemand, Tectonic erosion along the Japan and Peru convergent margins, Geol. Soc. Am. Bull., 102, 704-720, 1990.

von Huene, R., and D. W. Scholl, Observations at convergent margins concerning sediment subduction, subduction erosion, and the growth of continental crust, Rev. Geophys., 29(3), 279-316, 1991.

von Huene, R., and D. W. Scholl, The return of sialic material to the mantle indicated by terrigeneous material subducted at convergent margins, Tectonophysics, 219, 163-175, 1993.

von Huene, R., et al., A subducting seamount beneath the Mediterranean Ridge, Tectonophysics, 271, 249-261, 1997.

Willett, S. D., Dynamic and kinematic growth and change of a Coulomb wedge, in Thrust Tectonics, edited by K. R. McClay, pp. 19-32, Chapman and Hall, New York, 1992.

Wortel, M. J. L., S. D. B. Goes, and W. Spakman, Structure and seismicity of the Aegean subduction zone, Terra Nova, 2, 554-562, 1990.

D. Klaeschen, GEOMAR, Marine Geodynamics, Wischhofstrasse 1-3, D-24148 Kiel, Germany.

A. Kopf, Scripps Institution of Oceanography, UCSD, 9500 Gilman Drive, La Jolla, CA 92093-0244, USA. (akopf@ucsd.edu)

J. Mascle, CNRS Géosciences Azur, BP 48, F-06235 Villefranche-surMer Cédex, France. (mascle@obs-vlfr.fr) 


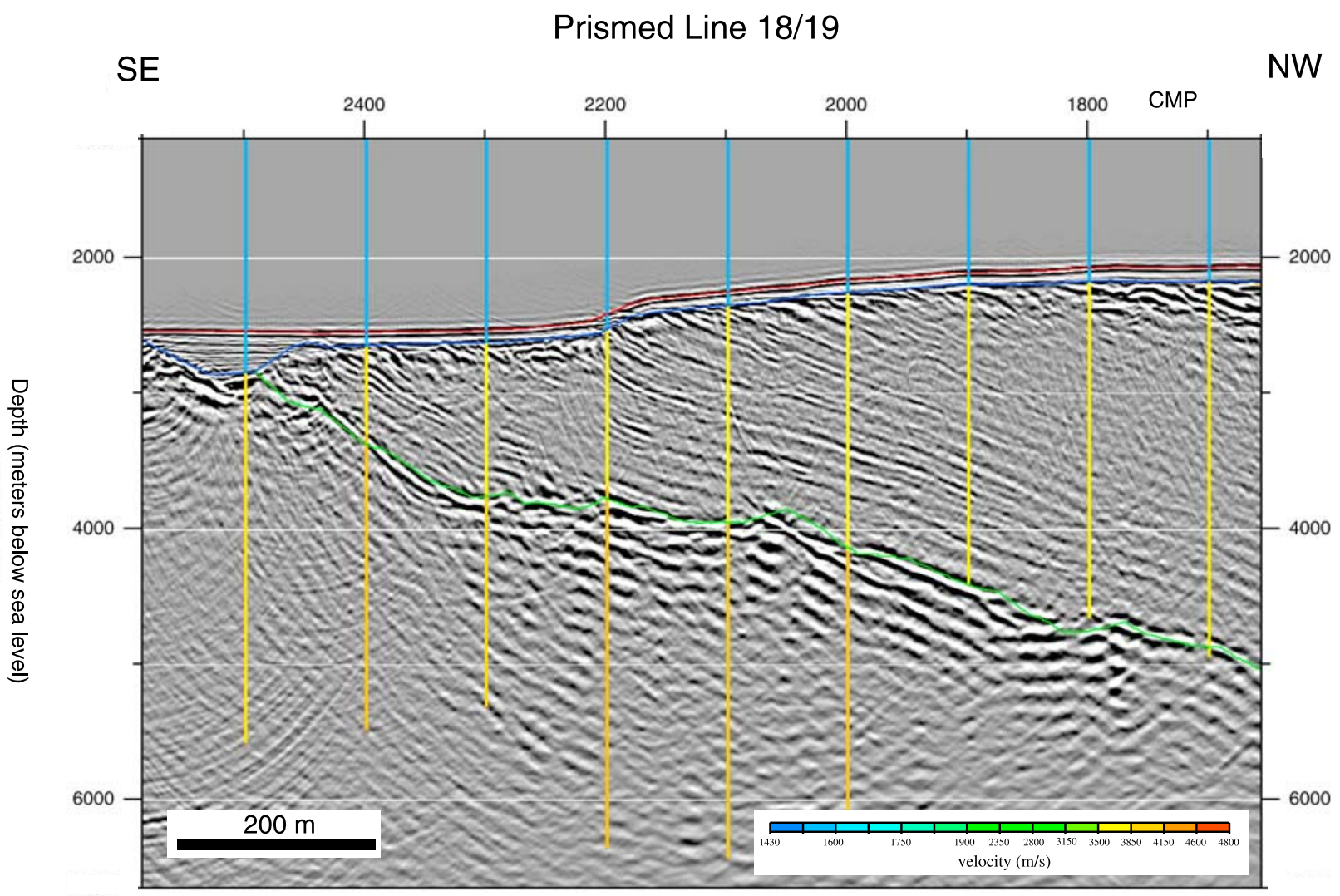

Figure 6. Sample seismic section across the backstop domain of line 18/19, south of Crete. Columns in rainbow shading illustrate the optimum velocity information gained from prestack depth migration using depth focusing analyses from "velocity scans". This part of the section was migrated with velocities ranging from 2100 to $4800 \mathrm{~m} \mathrm{~s}^{-1}$ (300 $\mathrm{m} \mathrm{s}^{-1}$ intervals); both velocities higher and lower than the ones shown resulted in blurred images and artificial curvature of events. 